\title{
Eff ective Assistance of Counsel: The Sixth Amendment and the Fair Trial Guarantee
}

Constitutional claims of incompetent counsel arise when a criminal defendant attacks his conviction on the ground that it was obtained at a trial at which he was represented by incompetent counsel. ${ }^{1}$ The courts disagree over both the source and the scope of any constitutional requirement that counsel be competent. Most courts find a right to competent counsel in the sixth amendment, but require the defendant who seeks to establish a violation of that right to show both that counsel was incompetent and that, but for counsel's incompetence, the defendant might have been acquitted. Other courts that rely on the sixth amendment only require the defendant to show that counsel was incompetent in order to obtain a new trial. Still other courts find no right to competent counsel in the sixth amendment at all. These courts view questions of counsel incompetence as a form of attack on a verdict under the fair trial guarantee of the due process clause. Accordingly, these courts require the defendant to show that counsel's alleged incompetence denied the defendant a fair trial. ${ }^{2}$

This comment will argue that the history and subsequent Supreme Court interpretation of the sixth amendment do not support any sixth amendment right to competent counsel other than a right to the appointment of counsel who appears, at the time of appointment, to be capable of mounting a competent defense (counsel who appears competent "ex ante"). Any attempt to read

1 This comment focuses on pre-trial and trial representation, and does not address directly attacks on counsel's competence in sentencing proceedings following a valid conviction. However, the comment's general approach, particularly its emphasis on due process rather than the sixth amendment, is as applicable to claims relating to sentencing as to those relating to the determination of guilt. Formulation of the precise standard of review required by due process for counsel's competence in the sentencing phase is beyond the scope of this comment.

2 The Supreme Court has never squarely addressed the issue of incompetent counsel claims, although it has had numerous opportunities to do so. See, e.g., Maryland v. Marzullo, 435 U.S. 1011 (1978) (White, J., dissenting from denial of certiorari) and cases cited therein. At this writing, the Court has before it two cases presenting the issue of appropriate constitutional standards for judicial review of incompetent counsel claims. See Washington v. Strickland, 103 S. Ct. 2451 (1983), granting cert. to 693 F.2d 1243 (5th Cir. 1982) (en banc); United States v. Cronic, 103 S. Ct. 1182 (1983), granting cert. to 675 F.2d 1126 (10th Cir. 1982). 
into the sixth amendment a substantive right to counsel who, in fact, provides the defendant with a competent defense is, at best, a poor proxy for the defendant's substantive right to a verdict that is reliable beyond a reasonable doubt. At worst, such a reading improperly constitutionalizes and hence federalizes every possible error at trial. The comment contends that a defendant is indeed entitled to representation that does not cast doubt on the reliability of the verdict, but that the right to such representation is found not in the sixth amendment but in the fair trial guarantee of the due process clause. Finally, the comment analyzes the effect on the availability of post-conviction remedies of its proposed bifurcation of the right to competent counsel into a right to the appointment of counsel who appears competent ex ante and a right to a reliable verdict. It concludes that the proposal will neither curtail nor substantially expand the availability of such remedies.

\section{INTRODUCTION}

In recent years, criminal defendants have increasingly resorted to incompetent-counsel claims as a means of raising a variety of objections to their convictions. Any such objection may be transformed into an incompetent counsel claim by alleging that counsel was remiss in allowing the source of the underlying claim to arise. ${ }^{3}$ The treatment of incompetent counsel claims varies dramatically from one jurisdiction to another. As the following example demonstrates, there is much at stake in the resolution of these conflicting standards.

Imagine two defendants convicted in different states. The first, convicted by overwhelming evidence, wishes to attack his conviction by raising a non-constitutional claim, for example, that a prosecution witness was allowed to offer hearsay testimony. ${ }^{4}$ The defendant's lawyer objects unsuccessfully to this testimony at trial. On appeal, the state court finds error but concludes that, in view of the overwhelming evidence of the defendant's guilt, the error was not sufficiently prejudicial to merit a new trial. ${ }^{5}$ The state collateral-attack court declines review because state law bars collateral

- See Tague, Federal Habeas Corpus and Ineffective Representation of Counsel: The Supreme Court Has Work to Do, 31 StaN. L. REv. 1, 56-61 (1978) (noting that limits on habeas review may be bypassed by raising incompetent counsel claims).

- See, e.g., Nelson v. Estelle, 642 F.2d 903 (5th Cir. 1981).

${ }^{5}$ Cf. Chapman v. California, 386 U.S. 18, 20, $23 \&$ n.7 (1967) (discussing state law harmless-error provision). 
attack on issues that have been or could have been decided on appeal. ${ }^{8}$

The second defendant, convicted on a far weaker case, wishes to attack his conviction by raising a constitutional claim, for example, that the state introduced the recorded testimony of an absent witness into evidence without making a good faith effort to produce that witness. ${ }^{7}$ There is a strong possibility that the witness would have testified differently had he been produced. Though he objected to this evidence at trial, the defendant's lawyer fails to raise this constitutional claim on appeal, and again the state collateral-attack court refuses a hearing on the ground that claims that could have been raised on appeal may not be raised on collateral attack.

Both defendants petition a federal court for a writ of habeas corpus. In order to obtain habeas review, each defendant transforms his underlying claim into an incompetent counsel claim. ${ }^{8}$ The first defendant alleges that his counsel incompetently failed to interview the offending prosecution witness, thereby failing to discover the damaging hearsay subsequently offered at trial, and incompetently failed to adduce the proper arguments in attacking the witness's testimony as hearsay at trial or on appeal. The second defendant alleges that his counsel incompetently assessed the strength of his confrontation clause claim and incompetently failed to pursue that claim on appeal.

- A number of states follow this rule. See L. YackLe, Postconviction Remedies $§ \S 5-6$, 10-11 (1981).

${ }^{7}$ See Barber v. Page, 390 U.S. 719 (1968).

- See supra text accompanying note 3 . Before seeking relief in the federal courts, both defendants are required to exhaust their state remedies by presenting their incompetent counsel claims to the state collateral-attack court. Wainwright v. Sykes, 433 U.S. $72,80-81$ (1977). It is therefore assumed that the state court dismissed the petitions, applying one of the approaches discussed below. See infra notes 27-34, 83-90, 122-37 and accompanying text. In many state courts, collateral review may be barred by counsel's procedural default. Some state courts, however, will forgive a procedural default where the default is found to be a product of counsel's incompetence. See, e.g., Wilson v. State, 284 Md. 664, 676, 399 A.2d 256, 262 (1979).

On habeas review, the first defendant can raise only his incompetent counsel claim; his underlying claim is non-constitutional and therefore not cognizable on federal habeas review. Rose v. Hodges, 423 U.S. 19, 21-22 (1975). The second defendant's underlying constitutional claim is barred by his procedural default on appeal unless he can show both cause for the default and actual prejudice attributable to the underlying claim. Wainwright $v$. Sykes, 433 U.S. 72 (1977). The "cause and prejudice" requirement might not bar either defendant from raising an incompetent counsel claim because counsel's failure to attack his own incompetence is sometimes held not to constitute a procedural default. Compare, e.g., Snyder v. State, 262 N.W.2d 574 (Iowa 1978) (default) with, e.g., Commonwealth v. Hare, 486 Pa. 123, 404 A.2d 388 (1979) (no default). 
The federal habeas court to which the first defendant applies for relief construes the sixth amendment to guarantee competent counsel. ${ }^{9}$ The court defines competence as the fulfillment of specific duties of counsel, here the duties to interview available witnesses and research the applicable law. ${ }^{10}$ The court holds an evidentiary hearing and concludes that counsel breached his duty to interview the witness and to develop the legal argument that would have established at trial that the damaging testimony was inadmissible. ${ }^{11}$ Accordingly, the court grants the writ without inquiring into the effect of this breach on the reliability of defendant's conviction.

The second federal habeas court requires the defendant seeking relief on an incompetent counsel claim to show not only that counsel was incompetent, but also that this incompetence was likely to have affected the outcome of his trial..$^{12}$ Emphasizing that counsel's actions are not to be judged in hindsight, ${ }^{13}$ the court examines the trial record and finds that counsel presented a vigorous defense that revealed most of the weaknesses in the prosecution's case, ${ }^{14}$ and determines that counsel's decision to pursue the defendant's other claims on appeal was reasonable given what counsel knew at the time. ${ }^{15}$ Accordingly, the court determines that counsel was competent, and denies the writ without reaching the issue of

- E.g., Moore v. United States, 432 F.2d 730, 737 (3d Cir. 1970). See infra notes 35-69 and accompanying text for discussion of the validity of construing the sixth amendment to guarantee competent counsel.

${ }^{10}$ E.g., Coles v. Peyton, 389 F.2d 224, 226 (4th Cir.), cert. denied, 393 U.S. 849 (1968). See infra notes 83-120 and accompanying text for an evaluation of this approach.

11 See, e.g., United States v. Decoster, 624 F.2d 196, 279 \& n.82 (D.C. Cir. 1979) (en banc) (Bazelon, J., dissenting); Morrow v. Parratt, 574 F.2d 411 (8th Cir. 1978).

12 E.g., United States v. Decoster, 624 F.2d 196, 206-08 (D.C. Cir. 1979) (en banc); Cooper v. Fitzharris, 586 F.2d 1325, 1331-33 (9th Cir. 1978) (en banc), cert. denied, 440 U.S. 974 (1979). This view of the right to competent counsel is discussed infra notes 27-82 and accompanying text.

Some courts that adopt this approach recognize that counsel may owe various specific duties to the defendant. These courts view such duties as matters of professional responsibility, however, and not as violations of the sixth amendment. Breach of a duty is admissible merely as evidence on the issue of overall competence. See, e.g., United States v. Decoster, 624 F.2d at 209.

1s See, e.g., United States v. Decoster, 624 F.2d 196, 208 (D.C. Cir. 1979) (en banc); Cooper v. Fitzharris, 586 F.2d 1325, 1328-30 (9th Cir. 1978) (en banc), cert. denied, 440 U.S. 974 (1979).

14 For an example of this reasoning, see Crismon v. United States, 510 F.2d 356, 357-58 \& n.3 (8th Cir. 1975).

${ }^{16}$ Cf. Hatkins v. Wyrick, 552 F.2d 1308, 1313 (8th Cir. 1977) (failure to raise claim that defendant was incompetent to stand trial not ineffective assistance where defense counsel had no knowledge of defendant's mental condition prior to trial). 


\section{actual prejudice. ${ }^{16}$}

The disparity in the treatment of these two defendants is startling. ${ }^{17}$ The first defendant is able to obtain a new trial without calling his legal guilt into question, and without asserting any violation of an underlying constitutional right. The second defendant is denied relief despite the presence of constitutional error possibly impeaching the reliability of his conviction.

Since almost every conceivable underlying claim can be converted into an incompetent counsel claim, ${ }^{18}$ the choice of standards for reviewing incompetent counsel claims significantly affects the system of state and federal postconviction remedies, ${ }^{19}$ the enforcement of state procedural rules, ${ }^{20}$ and the substantive content of the constitutional rights of defendants generally. ${ }^{21}$ The current treatment of incompetent counsel claims in the courts raises several im-

${ }_{16}$ This approach was outlined in Washington v. Strickland, 693 F.2d 1243, 1250-58 (5th Cir. 1982) (en banc), cert. granted, 103 S. Ct. 2451 (1983).

17 Although the first defendant's success is less common than the second defendant's failure because the legal doctrines that enabled the first defendant to obtain relief are employed by only a small minority of courts, such success is by no means unheard of. See infra notes 83-90 and accompanying text. At the state court level, even greater disparities are evident in the standards of review of incompetent counsel claims. See Annot., 2 A.L.R. 4TH 27, 109-57 (1980). Moreover, some state courts maintain standards that differ from those used by the federal courts in that state. See id. at 61-62; Cover \& Aleinikoff, Dialectical Federalism: Habeas Corpus and the Court, 86 YaLE L.J. 1035, 1060-64 (1977). The need for uniformity in treating incompetent counsel claims thus implicates not only the rights of defendants, but also the relations between state and federal courts.

${ }^{18}$ See supra note 3 and accompanying text.

10 The generous reading given the sixth amendment by the federal court hearing the petition of the first defendant in the example allows an underlying, non-constitutional claim to be converted into a constitutional one. This expedient permits that defendant to obtain federal habeas relief without the showing of prejudice the state court would require before granting relief on the underlying, non-constitutional claim.

${ }^{20}$ A slightly modified version of the first example demonstrates such an effect. If the first defendant's non-constitutional claim had not been raised at trial, state procedural rules would have deemed it waived and would therefore have barred it on appeal or collateral attack. The first federal court's approach to incompetent counsel claims would nonetheless permit the defendant to raise such a defaulted claim as an incompetent counsel claim, thereby avoiding the state procedural default rule even as to a wholly state law claim. See infra notes 110-20 and accompanying text.

23 The treatment of the second defendant illustrates the problems caused by a definition of competence that turns on a lawyer's errors without regard to prejudice. In the example, the lawyer's default frustrated the defendant's efforts to get a hearing of his claim on the merits, despite the fact that that claim might have cast serious doubts on his conviction. Because, on the whole, counsel's performance could not be deemed "incompetent," review of the effect of this particular action by counsel was precluded. This approach thus makes the reviewing court's finding of competence or incompetence crucial. A defendant whose lawyer falls just above the threshold level of competence defined by the appellate court receives a categorically different level of protection than one whose lawyer falls just below that threshold. 
portant constitutional questions. The first is whether the right-tocounsel clause of the sixth amendment includes any guarantee of competent counsel at all. ${ }^{22}$ A second question is whether that guarantee is predicated upon showing prejudice in addition to incompetence, and, if so, what showing of prejudice suffices. ${ }^{23} \mathrm{~A}$ third is whether the due process guarantee of a fair trial, to which incompetent counsel claims were originally referred, has indeed been superseded by the "overlapping but more stringent standards" of the sixth amendment. ${ }^{24}$ If not, the substantive content of the fair trial guarantee, which the Court has elaborated only indirectly, must be addressed head-on. ${ }^{25}$

Despite the courts' varying descriptions of and sources for the right to effective assistance of counsel, all formulations of that right are an amalgam of two characterizations, one procedural or dignitary, the other substantive. The procedural characterization endows the right to effective assistance of counsel with an abstract importance, independent of the impact of the infringement of that right on the reliability of the verdict; the substantive characterization of the right views it as concerned only with the impact of ineffective counsel on the outcome of the trial. The thesis of this comment is two-fold. First, the comment asserts that the source in the text of the Constitution of a defendant's substantive right to effective assistance of counsel is the due process clauses of the fifth and fourteenth amendments; the procedural right to effective assistance is located in the sixth amendment. Second, the comment asserts that a defendant has no procedural right to competent counsel beyond a right to the appointment of counsel who appears competent at the time of appointment; the defendant's substantive right to effective assistance, however, protects the defendant from any act or omission of counsel that casts doubt upon the reliability of the defendant's verdict.

\section{Sixth Amendment Approaches to the Right to Competent COUNSEL}

The sixth amendment, which provides that "[i]n all criminal prosecutions, the accused shall enjoy the right . . . to have the Assistance of Counsel for his defence,"28 seems the logical place to

${ }^{22}$ See infra notes 35-69 and accompanying text.

${ }^{28}$ See infra notes 33, 138-77 and accompanying text.

24 Scott v. United States, 427 F.2d 609, 610 (D.C. Cir. 1970).

${ }^{25}$ See infra notes 138-77 and accompanying text.

28 U.S. Const. amend. VI. 
begin in considering what guarantees of competent counsel the Constitution affords. Courts that rely on the sixth amendment as the constitutional basis for a right to competent counsel have adopted two different interpretations of that right, the "prejudicial incompetence" approach and the "abstract competence" approach. The two are similar insofar as both depend upon the sixth amendment and both require some form of inquiry into counsel's "competence." They differ in that the former requires a defendant to show that prejudice resulted from counsel's incompetence, while the latter does not. This section analyzes and criticizes, on the basis of both history and policy, the underpinnings of both approaches. It argues that an independent inquiry into "competence" based on an abstract notion of competent counsel is undesirable. It also suggests that the sixth amendment, if properly construed, is of only limited aid to defendants seeking guarantees of competent counsel, and requires only that any counsel appointed by the trial court be competent at the time of appointment.

\section{A. The Prejudicial Incompetence Approach}

1. Description. All but three federal courts of appeals ${ }^{27}$ and a majority of state courts ${ }^{28}$ have now adopted some version of the prejudicial incompetence approach. Though there are many versions of this approach, they all share three common features. First, though incompetent counsel claims remain technically cognizable under the due process clauses, courts find there is no need to engage in due process analysis because that analysis has been superseded by the "overlapping but more stringent" requirements of the sixth amendment. ${ }^{29}$ Second, the right to counsel clause is found to include a right to competent counsel..$^{30}$ Third, only incompetence that prejudices the defense offends the sixth amendment; in order to obtain a new trial a defendant must establish both that counsel was "incompetent" and that counsel's incompetence adversely af-

${ }^{27}$ The three circuits that have not adopted the prejudicial incompetence approach are the Second, Sixth, and Tenth Circuits. See Washington v. Strickland, 673 F.2d 879, 896-900 \& nn.11-20 (surveying law in other circuits), rev'd, 693 F.2d 1243 (5th Cir. 1982) (en banc), cert. granted, 103 S. Ct. 2451 (1983).

${ }^{28}$ See Annot., 2 A.L.R. 4TH 27, 109-41 (1980) (surveying law in the state courts).

${ }^{29}$ E.g., Scott v. United States, 427 F.2d 609, 610 (D.C. Cir. 1970).

so E.g., Dyer v. Crisp, 613 F.2d 275, 278 (10th Cir.), cert. denied, 445 U.S. 945 (1980); Moore v. United States, 432 F.2d 730, 737 \& n.27 (3d Cir. 1970) (en banc). The right to competent counsel has been held to be either a right to counsel who is generally competent or a right to counsel who discharges certain specific duties. See infra notes 34,88 and accompanying text. 
fected the defense. ${ }^{31}$

Significant variation exists in the application of the prejudicial incompetence approach. Courts using this approach disagree as to both the standard of competence the sixth amendment guarantees and the degree of prejudice that must be shown to make out a violation of that guarantee. Yet most courts do seem to agree that only gross and obvious errors constitute incompetence for sixth amendment purposes, ${ }^{32}$ and that the defendant must show that counsel's incompetence is likely to have affected the outcome of the trial. ${ }^{33}$ The manner of employing the test also varies from court to court. As a general rule, however, defendants are required first to show that counsel was incompetent overall and then to demonstrate some further, specific harm going to the reliability of the verdict. $^{34}$

31 E.g., Cooper v. Fitzharris, 586 F.2d 1325, 1331-33 (9th Cir. 1978) (en banc), cert. denied, 440 U.S. 974 (1979); McQueen v. Swenson, 498 F.2d 207, 218-20 (8th Cir. 1974).

${ }^{32}$ The courts typically use such language as "reasonably effective," e.g., Washington v. Strickland, 693 F.2d 1243, 1250 (5th Cir. 1982) (en banc), cert. granted, 103 S. Ct. 2451 (1983), or "within the range of competence expected of attorneys in criminal cases," e.g., United States v. Bosch, 584 F.2d 1113, 1121 (1st Cir. 1978); see infra notes 88-90 and accompanying text; see also McMann v. Richardson, 347 U.S. 759, 774 (1970); Cooper v. Fitzharris, 586 F.2d 1325, 1330 (4th Cir. 1978) (en banc), cert. denied, 440 U.S. 974 (1979).

ss See Washington v. Strickland, 673 F.2d 879, 896-900, nn.11-20 (discussing the law in the federal circuit courts), rev'd, 693 F.2d 1243 (5th Cir. 1982) (en banc), cert. granted, 103 S. Ct. 2451 (1983); Annot., 2 A.L.R. 4TH 27, 109-41 (1980) (discussing the law in the state courts). This standard does not hold sway in all courts, however. A substantial minority requires only that the defendant show a genuine possibility that the outcome was adversely affected. See, e.g., Cooper v. Fitzharris, 586 F.2d 1325, 1333 (9th Cir. 1978) (en banc), cert. denied, 440 U.S. 974 (1979). A few courts have held that a substantial adverse impact on the defense satisfies the prejudice requirement without regard to any definite effect on the outcome. See, e.g., Washington v. Strickland, 693 F.2d 1243, 1262 (5th Cir. 1982) (en banc), cert. granted, 103 S. Ct. 2451 (1983); United States ex rel. Green v. Rundle, 434 F.2d 1112, 1115 (3d Cir. 1970).

34 Many courts using this approach treat the two steps as completely independent. These courts are able to avoid the issue of prejudice by finding counsel's overall performance competent as an initial matter. See, e.g., Langford v. State, 354 So. 2d 297, 307-09 (Ala. Crim. App.), rev'd on other grounds, 354 So. 2d 313 (Ala. 1977); Green v. State, 579 P.2d 14, 16 (Alaska 1978); Allen v. Hopper, 234 Ga. 642, 643, 217 S.E.2d 156, 157 (1975); State v. McNulty, 60 Hawaii 259, 269-70, 588 P.2d 438, 446 (1978), cert. denied, 441 U.S. 961 (1979); State v. Hyatt, 281 N.W.2d 716, 716 (Minn. 1979). They can also avoid the issue of competence entirely by finding the specific errors alleged insufficiently prejudicial. See, e.g., Gustave v. United States, 627 F.2d 901, 904 (9th Cir. 1980); People v. Tripp, 19 Ill. App. 3d 200, 204-05, 311 N.E.2d 168, 172 (1974); State v. King, 262 N.W.2d 709, 710 (Minn. 1978); Commonwealth v. Walley, 262 Pa. Super. 496, 504, 396 A.2d 1280, 1284 (1978).

Other courts intertwine the inquiries. Some have suggested that prejudice sufficient to reverse must have been foreseeable and that a generally creditable performance is not rendered defective by a single mistake. See, e.g., Springer v. Collins, 586 F.2d 329, 332-33 (4th Cir. 1978), cert. denied, 440 U.S. 923 (1979); United States v. Allen, 554 F.2d 398, 404 (10th Cir.), cert. denied, 434 U.S. 836 (1977). By contrast, some cases suggest that a single error, if 
2. Analysis.

a. Authority for the Prejudicial Incompetence Approach. The heart of the prejudicial incompetence approach is its requirement of a two-step inquiry: first, a general showing of overall incompetence by counsel, and second, a specific instance in which that incompetence genuinely prejudiced the defendant's case. The basis for this two-step inquiry, and the basis for the prejudicial incompetence approach in general, is found in dicta from several Supreme Court decisions interpreting the scope of the right to counsel. ${ }^{35}$ That right, argue the proponents of the prejudicial incompetence approach, includes a right to effective counsel, understood as counsel who is competent or whose incompetence does not prejudice the defense. ${ }^{36}$

What little historical evidence exists suggests that the right to counsel clause was originally intended only to protect "the right of an accused in a criminal prosecution in a federal court to employ a lawyer to assist in his defense."37 The government's obligation was a negative one. It could not interfere in a defendant's decision or efforts to obtain counsel. Neither could it prevent his counsel from appearing. No affirmative responsibilities either to provide counsel or to ensure his effectiveness were originally intended. ${ }^{38}$

sufficiently egregious, may be grounds for bypassing the question of counsel's overall performance and granting a new trial. See, e.g., Nero v. Blackburn, 597 F.2d 991, 994 (5th Cir. 1979); United States ex rel. Lee v. Rowe, 446 F. Supp. 1039, 1048 (N.D. II. 1978); Commonwealth v. Roundtree, 469 Pa. 241, 248-51, 364 A.2d 1359, 1362-64 (1976).

${ }^{3 s}$ See McMann v. Richardson, 397 U.S. 759, 771 n.14 (1970); Reece v. Georgia, 350 U.S. 85, 90 (1955) (interpreting due process clause); Glasser v. United States, 315 U.S. 60, 69-70 (1942); Avery v. Alabama, 308 U.S. 444, 446 (1940) (interpreting due process clause). The reach and meaning of these dicta are discussed infra notes 47-57 and accompanying text.

${ }^{38}$ See, e.g., Cooper v. Fitzharris, 586 F.2d at 1325, 1329 (9th Cir. 1978) (en banc), cert. denied, 440 U.S. 974 (1979).

${ }^{37}$ Scott v. Illinois, 440 U.S. 367,370 (1979).

ss See W. Beaney, The Right to Counsel in American Courts 27-36 (1955). Professor Beaney cites evidence from the first Congress to demonstrate that the sixth amendment did not concern the appointment of counsel. The Judiciary Act of 1789 provided for criminal defendants to plead and manage their own cases "personally or by the assistance of such counsel . . . as by the rules of the said court . . . shall be permitted to manage and conduct causes therein." Judiciary Act of 1789, $\S 35,1$ Stat. 73, 90 (emphasis added). The day following passage of the Judiciary Act, the sixth amendment was proposed by Congress to the states without any discussion to suggest that the right to counsel clause altered this statutory rule. W. BEANEY, supra, at 28.

A second act, adopted by Congress several months prior to the ratification of the sixth amendment, provided for the appointment of counsel in capital cases. See Act of April 15, 1790, § 29, 1 Stat. 112, 118-19. As Professor Beaney points out, "[i]f the proposed Sixth Amendment counsel provision included a guaranty of appointed counsel in all felony cases, why did Congress pass this halfway measure?" W. BEANEY, supra, at 28.

This hypothesis about the original reach of the right to counsel clause is supported by 
In light of this apparent original intent, it is difficult to argue that the right to counsel clause was intended specifically to guarantee all defendants that the state bear the risk of defense counsel's incompetence. ${ }^{39} \mathrm{It}$ is most unlikely that the right to counsel clause was intended to oblige the state to bear the risk of prejudicial errors by the attorney into whose presence, identity, or choice of defense the state was prevented from intruding. To argue that the original intent of the sixth amendment included a guarantee of attorney competence gives the right to counsel clause, construed according to its drafters' understanding, a distinctly peculiar cast. On the one hand, indigent defendants would have no guarantee of the benefit of counsel at all; on the other hand, defendants able to retain counsel would be guaranteed by the state that their retained counsel would perform competently at trial.

This is not to suggest that the Supreme Court must restrict the right to counsel clause, in accordance with its originally intended meaning, to a guarantee of unhindered freedom to hire a lawyer. The Court has already "departed from the literal meaning of the Sixth Amendment."40 Nonetheless, the likely original meaning of the right to counsel clause should serve as a reference point for measuring the extent the Court has given to those departures. ${ }^{41}$

the fact that throughout the nineteenth century and into the beginning of the twentieth no federal appeals were brought alleging denial of the right-to have counsel appointed as a violation of the sixth amendment. See id. at 29-31. In practice both the federal government and many states provided by statute for appointment of counsel in capital cases, and, by the turn of the century, the custom in many federal courts was to appoint counsel routinely in felony cases. Id. at 29-30. The common understanding seems to have been that this custom was an exercise of the court's supervisory power and not a matter of constitutional right. Id.

The Supreme Court's approach to developing the right to have counsel appointed provides additional indirect confirmation that such a right was not intended by the framers. Neither in Johnson v. Zerbst, 304 U.S. 458 (1938), nor in Gideon v. Wainwright, 372 U.S. 335 (1963), did the Court argue that historical evidence supported an indigent's sixth amendment right to have counsel appointed; Zerbst relied purely on policy considerations, 304 U.S. at 462-63, and Gideon simply relied on Zerbst's reading of the sixth amendment, 372 U.S. at 339-40. This omission is all the more remarkable because in Betts v. Brady, 316 U.S. 455 (1942) (overruled in Gideon v. Wainwright, 372 U.S. 335, 342 (1963)), the Court concluded, largely on the basis of historical evidence, that similarly worded provisions in a state constitution did not include a right to have counsel appointed. Id. at 465-71.

39 See United States v. Decoster, 624 F.2d 196, 219, 220 (D.C. Cir. 1979) (en banc) (MacKinnon, J., concurring). Apart from this historical evidence, the language of the clause could bear such a reading; "enjoy the right . . . to have the Assistance of Counsel," U.S. CoNST. amend. VI, might be read to bestow on defendants a right to an attorney who will in fact assist in the defense. Prejudicial incompetence could then be said to deny the assistance such a right demands.

to Scott v. Illinois, 440 U.S. 367,372 (1979).

${ }^{11}$ Cf. Schneckloth v. Bustamonte, 412 U.S. 218, 254-56 (1973) (Powell, J., concurring) (discussing the relevance of the historical purpose of the writ of habeas corpus for the writ's 
The first relevant departure occurred in Johnson $v$. Zerbst ${ }^{42}$ and Gideon $v$. Wainwright. ${ }^{4}$ These cases establish the right of an indigent defendant to have counsel appointed by the court at the state's expense. ${ }^{44}$ The opinions do not themselves indicate whether providing the indigent with a lawyer suffices or whether the state, at least to some extent, must also guarantee that lawyer's competence; nor do the opinions discuss the rights of non-indigent defendants. Zerbst and Gideon simply transplant the right of indigent defendants to appointed counsel, first enunciated in Powell v. Alabama, ${ }^{45}$ to the sixth amendment, and, in so doing, extend that right to successively larger classes of cases. ${ }^{46}$

Lower courts that have adopted approaches to the right to competent counsel based on the sixth amendment read considerably more into these sixth amendment cases than the right to have counsel appointed. These courts hold that the Supreme Court's references to a right to "effective assistance of counsel,"47 and similar expressions in cases such as Powell, ${ }^{48}$ Avery v. Alabama," Glasser v. United States, ${ }^{50}$ and Reece $v$. Georgia, ${ }^{51}$ demonstrate that the Court reads the sixth amendment as a guarantee of counsel who actually performs competently at trial. ${ }^{52}$ The watershed case for this interpretation of the right to competent counsel was

contemporary constitutional scope).

42304 U.S. 458 (1938).

43 372 U.S. 335 (1963).

4 The groundwork for these departures from the original intent of the right to counsel clause was laid in Powell v. Alabama, 287 U.S. 45 (1932). In Powell, the Court held that the due process clause of the fourteenth amendment included the right of an indigent defendant to have counsel appointed in a capital case. The trial court had initially appointed the entire local bar and made a more specific appointment only on the morning of trial. The Court held that the duty to appoint "is not discharged by an assignment at such a time or under such circumstances as to preclude the giving of effective aid." Id. at 71 .

4828 U.S. 45 (1932); see supra note 44.

18 Powell held that due process requires appointment of counsel for indigent defendants in capital cases. 287 U.S. at 71 . Zerbst held that the sixth amendment requires appointment of counsel for indigents in all federal criminal cases. 304 U.S. at 463 . Gideon applied this aspect of the sixth amendment to the states via the fourteenth amendment. 372 U.S. at 342. Subsequent decisions delineating the limits of the holding in Gideon do not alter the limited nature of the right discussed, namely, the right of an indigent defendant to have counsel appointed. See, e.g., Scott v. Illinois, 440 U.S. 367, 373 (1979).

47 E.g., Cuyler v. Sullivan, 446 U.S. 335, 345 (1980).

487 U.S. at 71 ("effective aid in the preparation and trial of the case").

49 308 U.S. 444, 446 (1940) ("The Constitution's guarantee of assistance of counsel cannot be satisfied by mere formal appointment.").

so 315 U.S. 60, 70 (1942) ("effective appointment of counsel").

s1 350 U.S. 85, 90 (1955) ("effective assistance of counsel").

52 See, e.g., Beasley v. United States, 491 F.2d 687, 692-93 (6th Cir. 1974); Coles v. Peyton, 389 F.2d 224 (4th Cir.), cert. denied, 393 U.S. 849 (1968). 
McMann v. Richardson. ${ }^{53}$ Prior to McMann, only a few courts and commentators insisted on reading the Supreme Court's opinions as establishing a sixth amendment guarantee that counsel perform effectively or competently; indeed, support for such a reading was scant. ${ }^{\text {s4 }}$ The Supreme Court's references in pre-McMann cases to the right to "effective assistance" of counsel refer, without exception, to the right to have the court exercise its authority in such a manner as not to prevent effective assistance. ${ }^{55}$ In McMann, the Court appeared to find a right to effective performance by counsel, stating that, "if the right to counsel guaranteed by the Constitution is to serve its purpose, defendants cannot be left to the mercies of incompetent counsel . . . ."168 Since that decision, most federal courts of appeals have adopted a general sixth amendment right to counsel who performs competently. ${ }^{87}$

s3 397 U.S. 759 (1970).

st See, e.g., United States v. Johnson, 318 F.2d 288, 291 (6th Cir. 1963); Goforth v. United States, 314 F.2d 868, 871 (10th Cir. 1963); Waltz, Inadequacy of Trial Defense Representation as a Ground for Post-Conviction Relief in Criminal Cases, 59 Nw. U.L. Rev. 289, 289-305 (1964).

${ }^{88}$ In Powell, the Court held the appointment of counsel to have been ineffective because it was made "at such a time and under such circumstances as to preclude the giving of effective aid." 287 U.S. at 71. Avery suggests only that appointment under circumstances not affording counsel a chance to prepare a defense may be an appointment that contravenes the sixth amendment-a proposition obvious after Powell-but then adds that such a claim may be rebutted by evidence showing that counsel actually performed competently. 308 U.S. at 445, 452. Glasser refers to effective assistance of counsel in the process of holding that to force the defendant to accept counsel with conflicting interests, like appointing counsel without adequate time for preparation, violates the defendant's sixth amendment rights. 315 U.S. at 176. Finally, Reece holds that a procedural default rule requiring challenges to the composition of a grand jury to be raised before indictment, if enforced against a defendant whose attorney was appointed after indictment, effectively reduces appointment to a useless formality and so contravenes the sixth amendment. 350 U.S. at 89-90. In all these cases, the notion of "effectiveness" is one of a requirement that the court not exercise the duty to appoint in such a manner as to prevent counsel's assistance from being effective. This is a far cry from an assurance that counsel will perform effectively.

Michel v. Louisiana, 350 U.S. 91 (1955), the companion case to Reece, provides additional evidence that the Court had found no right to competent performance of counsel in the sixth amendment. In rejecting defendant's claim that he was denied "effective representation" of counsel, the Court cited only a federal court of appeals opinion that decided a competency of counsel claim under the "farce and mockery" standard of the due process clause. Id. at 101 (citing United States ex rel. Feeley v. Ragen, 166 F.2d 976, 980 (7th Cir. 1948)). See infra notes 127-31 and accompanying text for a discussion of the "farce and mockery" standard.

s8 397 U.S. at 766 . As the discussion below demonstrates, this appearance is somewhat deceiving and is dispelled once such language is considered in context. See infra notes 61-69 and accompanying text.

${ }^{87}$ E.g., Cooper v. Fitzharris, 586 F.2d 1325, 1329 (9th Cir. 1978) (en banc), cert. denied, 440 U.S. 974 (1979); United States v. Bosch, 584 F.2d 1113, 1120-21 (1st Cir. 1978); Marzullo v. Maryland, 561 F.2d 541, 543 (4th Cir. 1977), cert. denied, 435 U.S. 1011 (1978); Beasley v. 
b. McMann. The defendant in McMann claimed that his guilty plea was invalid because entered on the erroneous advice of appointed counsel. The Court treated the defendant's attack on counsel's advice as a claim that the defendant had been induced to enter an unintelligent and therefore voidable guilty plea. ${ }^{58}$ It held that whether the plea was unintelligent turned "not on whether a court would retrospectively consider counsel's advice to be right or wrong, but on whether that advice was within the range of competence demanded of attorneys in criminal cases." added, in dictum, that "defendants facing felony charges are entitled to the effective assistance of competent counsel."Bo

Dicta, of course, may be persuasive, but the McMann Court offered no argument in support of its broad assertion beyond citation to Powell, Avery, Glasser, and Reece. ${ }^{61}$ References to "effective assistance" of counsel in these cases do not support a general right to competent counsel beyond the right to counsel who is competent when appointed. ${ }^{62}$ Moreover, the dictum comes in the context of a general admonition to trial courts to safeguard the rights of defendants and is thus more a suggestion of the trial court's duties than an explicit recognition of an independent constitutional right.

Any apparent support found in McMann for a right to competent performance by counsel must be understood in light of the ultimate issue in that case, the intelligence of McMann's waiver of numerous trial-related constitutional rights by pleading guilty. In order to evaluate the intelligence of the waiver, the Court in $M c$ Mann had to choose between engaging in a subjective inquiry into the defendant's actual understanding of his bargaining position in light of the state's evidence against him and using the quality of counsel's advice as an objective indicator of the intelligence of that waiver. The McMann Court chose the latter. ${ }^{63}$ Its emphasis on the

United States, 491 F.2d 687, 696 (6th Cir. 1974); Moore v. United States, 432 F.2d 730, 736$37 \&$ n.25 (3d Cir. 1970).

ss 397 U.S. at 766-75. A guilty plea, because it is a waiver of several fundamental rights related to trial, must be voluntary and intelligent. Brady v. United States, 397 U.S. 742, 748 (1970); see Johnson v. Zerbst, 304 U.S. 458, 464 (1938) (waiver of constitutional right must be voluntary, knowing, and intelligent).

397 U.S. at 771.

so Id.

o1 Id.

${ }_{62}$ See supra notes 42-57 and accompanying text.

${ }^{63}$ Cf. Tollett v. Henderson, 411 U.S. 258, 266 (1973) ("The focus of federal habeas inquiry [into a claim of having pled guilty on faulty advice of counsel] is the nature of the advice and the voluntariness of the plea ...."); L. YACKLE, supra note 6, § 80, at 320 
competence of counsel in the guilty-plea context is better seen as a concession to administrative ease in the face of the difficulties inherent in the analysis of a waiver than as a recognition of any general right to competent performance by counsel.

There is a still more compelling reason to read McMann's reference to competent counsel as a requirement limited to the guiltyplea context. The state has compelling reasons for seeing that guilty pleas are not upset. Not only are such pleas deemed particularly reliable, ${ }^{64}$ but the state interest in finality is strong where it has refrained from proving its case in reliance on the defendant's plea. ${ }^{65}$ Subsequent Supreme Court opinions have read McMann to find that strong state interests in not upsetting a guilty plea justify a constructive waiver of all of a defendant's claims except those going to the fact of his guilt. ${ }^{66}$ Yet, as the McMann court recognized, constructive waivers, however justified, may divest a defendant of otherwise valid claims that should not be foreclosed through the incompetent advice of defendant's counsel. ${ }^{67}$ To the argument that fairness requires that the defendant be left some means to raise meritorious claims that he would not have waived had he been fully informed, the Court has made a small concession: the defendant can attack counsel's competence in advising the defendant to plead guilty. ${ }^{68}$ By focusing on the overall quality

(arguing that the aim of the holding in McMann was to minimize the number of guilty pleas that will be upset on collateral attack). This emphasis by the Court on the quality of advice is analogous to the importance ordinarily attached by reviewing courts to the quality of explanations given by the trial court to a defendant who proposes to waive a fundamental right. See Faretta v. California, 422 U.S. 806, 835 (1975) (defendant who wishes to represent himself should be informed by court of dangers and disadvantages of waiving right to counsel); Von Moltke v. Gillies, 332 U.S. 708, 723-24 (1948) (plurality opinion) (in determining whether waiver of right to counsel is voluntary and intelligent, a court must make more than a "mere routine inquiry" in investigating circumstances of a case). In both areas the quality of the advice acts as a surrogate for an inquiry into the defendant's subjective understanding. The reasons for using such a surrogate are even stronger in a case such as McMann because the communications between lawyer and client are both privileged and outside the record, whereas those between judge and defendant are made in open court.

os See Tollett v. Henderson, 411 U.S. 258, 269 (1973) (justifying treatment of guilty plea as a constructive waiver of a defendant's other attacks on his conviction on the ground the defendant "has solemnly admitted in open court that he is in fact guilty of the offense with which he is charged"); Lefkowitz v. Newsome, 420 U.S. 283, 296 (1975) (White, J., dissenting) (guilty plea establishes guilt "by as reliable a method as is known to the criminal law-[the defendant's] solemn admission of guilt, made in open court").

${ }^{6 s}$ Lefkowitz v. Newsome, 420 U.S. 283, 289 (1975).

66 E.g., Tollett v. Henderson, 411 U.S. 258, 267 (1973); see McMann, 397 U.S. at 768, 772; L. YACKLE, supra note 6, \& 102. An exception is made for claims depriving the state of jurisdiction to try the defendant. See Blackledge v. Perry, 417 U.S. 21, 30-31 (1974).

67397 U.S. at 770-71; see infra note 68.

es This interpretation of the reasoning for McMann's allowance of attack on counsel's 
of counsel's advice, the Court avoided a result that would have required full review of the merits of the defendant's underlying claims in order to determine whether or not his waiver was unintelligent. ${ }^{69}$

competence is strengthened by the subsequent decision of the Supreme Court in Menna v. New York, 423 U.S. 61 (1975). In that case, the Court held that a guilty plea removes even the issue of factual guilt from the case, id. at $62 \mathrm{n} .2$, leaving only attacks on counsel's competence. Professor Yackle agrees that a guilty plea waives all constitutional fair-trial rights save the right to competent counsel:

[As an alternative to contesting his indictment], the defendant may choose self-conviction by way of a plea of guilty, in which case the defendant will have the benefits of any plea bargain that can be worked out with the prosecution but will give up the procedural safeguards that would attend a trial and the availability of further review of any alleged failure to respect those constitutional rights. A defendant who pleads guilty is left, accordingly, with only the claims that can be raised against the voluntariness of the plea itself ....

L. YACKLE, supra note $6, \S 102$, at 403 n.70.

${ }^{69}$ McMann, 397 U.S. at 768, 772; cf. Tollett v. Henderson, 411 U.S. at 258, 267 (1973) (claims of prior constitutional deprivations "are not themselves independent grounds for federal collateral relief").

Given these reasons for distinguishing $M c M a n n$, it can fairly be said that the lower courts have attached undue weight to its dictum concerning the right to competent counsel. Subsequent Supreme Court cases, most notably Cuyler v. Sullivan, 446 U.S. 335 (1980), have contained dicta similar to McMann's, but the Court has yet to countenance a procedural sixth amendment right to competent counsel unequivocally. In any event, such dicta certainly do not foreclose the possibility that the Court will adopt a more restrictive reading of the right to counsel clause when it fully considers the issue in a case that squarely presents it.

Cuyler states, albeit in dicta, that a new trial is required where the defendant can show that his counsel had an actual conflict of interest arising from joint representation and that this conflict adversely affected his counsel's performance, $i d$. at 350-even though the trial court had no notice as to that conflict of interest, $i d$. at 348, and even though counsel was retained, not appointed, $i d$. at 344-45. The Court's holding, read broadly, interprets the sixth amendment to include a procedural right to counsel who is free from conflicts of interest that adversely affect his performance. See id. at 349-50 (demonstration by defendant of an actual conflict makes out a sixth amendment violation without the need for a showing of prejudice). Because this procedural right refers to counsel's actual performance as part of the definition of the right, Cuyler establishes that the Court reads the sixth amendment to include at least one guarantee concerning counsel's actual performance: the state bears the risk that counsel's performance will be impaired by an actual conflict of interest.

In the limited context of conflict-of-interest cases, Cuyler represents a rejection of the analysis proposed in this comment. This comment's analysis, if applied to conflict-of-interest cases, would require reversal only if the trial court were on notice of the existence of a conflict (in which case there would be a breach of the trial court's duty to ensure counsel's competence ex ante, see infra notes 188-94 and accompanying text) or if an undisclosed conflict caused outcome-determinative prejudice to the defense (in which case the verdict would be unconstitutionally unreliable as a matter of due process, see infra notes 175-77 and accompanying text).

Nonetheless, there is good reason to adopt a different approach to incompetent counsel claims from that adopted by Cuyler for conflict-of-interest claims. The effects of a conflict of interest are cumulative and pervasive; it is ordinarily easier to identify the conflict than to determine its effects. See Glasser v. United States, 315 U.S. 60, 76 (1942) (once an actual 
c. Policy. Given the lack of historical support for a sixth amendment procedural right to competent counsel, it is unclear what end is served by requiring a preliminary showing of incompetence in addition to a showing of prejudice attributable to counsel's acts or omissions. One unavoidable problem in criminal trials is that of deciding which of the two parties should bear the risk of any errors by defense counsel. Many courts seem to use the incompetence requirement as a risk-allocating device.

An early approach to this problem of risk allocation held that the risk of an error should be borne by the party whose fault led to the error. Since a defendant's lawyer may be deemed his agent, the defendant can be held responsible if he chooses a bungling lawyer as his agent. ${ }^{70}$ Under this approach the defendant should always

conflict is shown, the court will not "indulge in nice calculations as to the amount of prejudice"). By contrast, the difficulty of making a hindsight assessment of competence is at least as great as the difficulty of determining the effects of counsel's conduct on the outcome of the trial. See infra notes 102-104 and accompanying text. Thus, inquiry into the presence of conflict of interest is a more appropriate surrogate for a case-by-case determination of prejudice than is an inquiry into the presence of incompetence.

Moreover, a conflict of interest handicaps any lawyer in his representation of the defendant, as do such other defects as senility, insanity, drunkenness, and disloyalty, regardless of the lawyer's skill. Such impediments to counsel's efforts can sensibly be singled out from the run of incompetent counsel claims for per se treatment. See Mitchell v. United States, 259 F.2d 787, 789 (D.C. Cir. 1958) (contrasting "skill" and "relative competence" with "physical or mental disability on the part of counsel, or . . . intoxication, fraud or misrepresentation, dual interest, insufficient time for preparation, or inadequate notice[,] ... [which] have special features"). Because the undivided loyalty of counsel is rightly viewed as an essential element of the the attorney-client relationship, conflicts also offend the accused's dignitary right to representation, cf. Powell v. Alabama, 287 U.S. 45, 56 (1932) (effective appointment of counsel requires that counsel be given "clear appreciation of responsibility [and] impressed with [an] individual sense of duty").

Finally, the scope of the holding in Cuyler is quite limited when read in light of Holloway v. Arkansas, 435 U.S. 475 (1978). Holloway requires reversal where the trial court, upon counsel's representation that a conflict has arisen, fails either to appoint substitute counsel or to determine that no conflict exists. Id. at 484. Thus, Cuyler applies only in the subclasses of cases in which either counsel fails to notify the trial court of the presence of a conflict of interest, or the trial court mistakenly determines that counsel's representations are unfounded. As to the latter cases, the state should clearly bear the risk of the trial court's error. As to the former, once one accepts the Court's premise that a conflict of interest is overwhelmingly likely to prejudice the defense, and given that counsel is charged under Holloway, 435 U.S. at 485-86, with the role and responsibility of detecting conflicts of interest in representing his clients, it is a very small step to the conclusion that the state should bear this particular risk in the small number of cases in which it will actually occur. By contrast, the adoption of a procedural sixth amendment right to competent counsel would shift a broad range of risks to the state in a very large number of cases. The policy argument against recognition of such a right will be taken up infra notes 91-120 and accompanying text. Plainly, Cuyler $v$. Sullivan leaves ample room for such arguments outside the narrow context in which that decision arose.

70 See, e.g., United States ex rel. Darcy v. Handy, 203 F.2d 407 (3d Cir.), cert. denied, 346 U.S. 865 (1953); People v. Stevens, 5 Cal. 2d 92, 98-99, 53 P.2d 133, 136 (1935); People 
bear the risk of any error by counsel. ${ }^{71}$

Although this agency theory has been generally abandoned, ${ }^{72}$ the notion of allocating risk by fault that underlies it has not. Only the means of determining fault has been changed. Under the prejudicial incompetence approach, defense counsel's incompetence is now used as the means of allocating the risk of counsel's error. Where error results from defense counsel's incompetence, the government is presumed at fault, and so it must bear the burden of counsel's error; where error does not result from counsel's incompetence, for example, where counsel fails to introduce exculpatory evidence because he had insufficient time to uncover it, the error is no one's fault, and hence no grounds exist for shifting the risk of that error from the party on whom it would otherwise fall, the defendant. ${ }^{\text {33 }}$

The allocation of the risk of defense-counsel error involves two assumptions: first, that counsel's incompetence implies fault on the part of the state while its absence precludes such fault; second, that errors by counsel are necessarily the fault either of the state or of the defendant and therefore that the risk of those errors can be allocated on the basis of such fault. Neither of these assumptions withstands scrutiny. Though the government has a duty to safeguard the rights of a defendant and ensure him a fair trial, ${ }^{74}$

v. Barnes, 270 Ill. 574, 579-80, 110 N.E. 881, 883 (1915); People v. Tomaselli, 7 N.Y.2d 350, 354, 165 N.E.2d 551, 554, 197 N.Y.S.2d 697, 700 (1960).

${ }^{71}$ See Waltz, supra note 54, at 296-97.

72 See Bines, Remedying Ineffective Representation in Criminal Cases: Departures from Habeas Corpus, 59 VA. L. REv. 927, 929 n.10 (1973).

${ }^{73}$ Courts that adopt the prejudicial incompetence approach assume that the sixth amendment protection it embodies exhausts the defendant's claims against the state stemming from the incompetence of his counsel. Unless the defendant can satisfy the two-step inquiry and show overall incompetence as well as prejudice, no new trial is granted for errors by counsel; the defendant must bear the risk of such errors even though they are not his fault and even though they adversely affect the outcome of his trial. See Cooper v. Fitzharris, 586 F.2d 1325, 1330 \& n.10 (9th Cir. 1978) (en banc) (collecting cases to that effect), cert. denied, 440 U.S. 974 (1979). As the present discussion demonstrates, not only is there little basis in reason for requiring an inquiry into "competence," but this requirement ignores the existence of the due process fair trial guarantee. It is the position of this comment that, under the fair trial guarantee, prejudicial error by counsel that is likely to be "outcome-determinative" requires a new trial regardless of whether counsel was otherwise competent. See infra notes 138-206 and accompanying text.

${ }^{74} \mathrm{Cf}$. Fitzgerald v. Estelle, 505 F.2d 1334, 1336-38 (5th Cir.) (finding of state action in connection with retained counsel's incompetence is necessary, and requires a showing "that some responsible state official connected with the criminal proceeding who could have remedied the conduct failed in his duty to accord justice to the accused."), cert. denied, 422 U.S. 1011 (1975). A trial court's general duty to safeguard the rights of defendants is fundamentally a matter of due process. From this premise, one can argue that the due process protection of defendants' rights, specifically the rights embodied in the incorporated sixth amend- 
the incompetence of defendant's counsel does not always result from a breach of that duty. Many aspects of counsel's performance either occur outside the trial court's notice or reasonably appear to be, though they are not in fact, competent. ${ }^{25}$ Thus, the existence of incompetence does not necessarily imply fault on the part of the state. Similarly, many errors, though the result of failures of communication between counsel and a confused and ignorant defendant, ${ }^{76}$ lack of time, ${ }^{77}$ tactical choice, or other factors not the product of counsel's incompetence, ${ }^{78}$ may cast doubt on the reliability of the defendant's verdict. The fact of competence does not preclude errors detrimental to the defendant that are not his fault. It seems unfair to shift the burden of all such errors to the defendant. ${ }^{79}$

A rejection of the chain of inference from incompetence to fault to risk allocation need not compel the abandonment of incompetence as a risk-allocating principle altogether. The use of

ment, requires the court to examine the competence of counsel. There is little doubt that the prejudicial incompetence approach is saturated with elements of due process protection, hence its focus on prejudice and the overlap in results between the prejudicial incompetence approach and a pure due process approach. See infra notes 201-07 and accompanying text. However, there is nothing in the due process clause that compels an examination of competence aside from the prejudicial effects of counsel's errors. See infra notes 138-77 and accompanying text. Nothing in the general due process notion of safeguarding defendants' rights supports or provides an excuse for undertaking the inquiry into competence of counsel. $I d$.

${ }^{75}$ See United States v. Decoster, 624 F.2d 196, $277-78$ \& n.78 (D.C. Cir. 1979) (en banc) (Bazelon, J., dissenting) (noting that counsel's most crucial work is done out of court and thus out of the judge's knowledge); see infra text following note 102.

76 The law, at least since Powell v. Alabama, 287 U.S. 45 (1932), has taken such handicaps of defendants into account. See id. at 68-73. The preclusiveness of a finding of general competence on the part of counsel is thus inconsistent with the solicitude for a defendant's inability to defend himself that runs through the decisions. See Johnson v. Zerbst, 304 U.S. 458,465 (1938) ("The purpose of the constitutional guaranty of a right to counsel is to protect an accused from conviction resulting from his own ignorance.").

${ }^{77}$ See Comment, Federal Habeas Corpus Review of Unintentionally Defaulted Constitutional Claims, 130 U. PA. L. Rev. 981, 996-98 (1982).

7s Decisions of counsel which turn out, in hindsight, to damage the defendant's case are frequently judged according to just such factors. See supra notes 13-15 and accompanying text. To the defendant, possibly convicted wrongfully, such solicitude for the realities of being an attorney is cold comfort. Moreover, a by-product of this judicial propensity to judge attorney competence in light of the time and resources available to the attorney is that defendants with limited resources or court-appointed attorneys are likely to bear the risks of attorney error disproportionately, even when their attorneys are personally able. See Comment, supra note 77, at 996-98 \& n.102.

29 It is the thesis of this comment that where an error by counsel that prejudices the defendant is the fault of neither party, the burden of that error should remain, as does the burden of prejudicial errors in general, on the party who has the original responsibility for showing the reliability of the verdict beyond a reasonable doubt, the government. See infra notes $165-77$ and accompanying text. 
fault as a risk-allocating principle is a vestige of the agency theory; it is certainly possible to eliminate fault and use incompetence directly. Such an approach would put the risk of all errors by defense counsel, regardless of prejudice, on the government if those errors result from counsel's incompetence. A theoretical justification for such an allocation could be based on the notion that a defendant has a procedural right to competence of counsel at trial; this is in essence the "abstract incompetence" approach. Standing alone, such a procedural right to competence is theoretically coherent. For a variety of reasons, which will be set forth in the next section, ${ }^{80}$ it is, however, practically undesirable. In any event, as the proponents of the abstract incompetence approach point out, a procedural right to competent counsel is obviously irreconcilable with the showing of prejudice required by the prejudicial incompetence approach. If a defendant has a procedural right to competent counsel, then a showing that his counsel was incompetent would demonstrate a violation of that right. Any inquiry into prejudice would be utterly unnecessary.

Despite the untenability of incompetence as a justification for shifting the burden of counsel's error, such burdens must still be allocated; one party or the other necessarily bears the risk. If incompetence is an inappropriate measure, the other half of the prejudicial incompetence approach, prejudice, must be pressed into service as a risk-shifting principle; where an error is prejudicial, the state should bear the risk.

If prejudice is to be the risk-allocating factor, then the incompetence inquiry becomes completely superfluous and the only defense for such an inquiry might be that it serves as a screening device for violations of the ultimate substantive right, freedom from outcome-determinative prejudice. Such a role depends on the validity of one of two inferences: either the presence of competent counsel implies the absence of prejudice, or the presence of incompetence implies the existence of prejudice. We have already seen that the former is unsound; the latter, that incompetence implies prejudice, is as easily refuted. A conviction resting on the eyewitness testimony of twenty bishops cannot be called into question by counsel's failure, on cross-examination, to raise the fact that one of them was the victim's uncle.

Of course, the lack of an absolute correlation between incompetence and prejudice does not rule out the argument that an in- 
competence inquiry is an administratively convenient screen for easy cases where no prejudice has occurred. Such an approach would lead to cases where a reviewing court would refuse to overturn a defendant's conviction even where counsel, though competent, committed prejudicial error. Even if we set aside the likely constitutional question that such a use of incompetence would raise, the justification for using incompetence as a proxy for prejudice, administrative convenience, is simply unfounded. Defining competence is an extremely difficult task, ${ }^{81}$ it is just as easy, if not easier, ${ }^{82}$ to determine prejudice directly.

Incompetence, though so employed by courts using the prejudicial incompetence approach, is irrelevant to the unavoidable task of allocating the risk of error between the defendant and the state. The remaining step in the inquiry, prejudice, allocates the risk of prejudicial error by counsel to the state, while leaving the risk of harmless error by counsel on the defendant. Thus, the prejudicial incompetence approach, while nominally recognizing a purely procedural right to counsel who performs competently, at bottom rejects such a right in favor of the substantive right to have one's guilt determined exclusive of counsel's outcome-determinative errors. This rejection, sub silentio, of the purely procedural right to counsel who performs competently accords with the conclusion suggested by our examination of the sixth amendment's history.

\section{B. The Abstract Competence Approach}

1. Description. Two federal courts of appeals and one state employ the "abstract competence" approach. ${ }^{83}$ Most recent law review commentary urges adoption of this approach in whole or in

-1 See infra notes 102-08 and accompanying text.

"2 Determining whether an error is prejudicial and, if so, whether that prejudice is outcome determinative is a task familiar to judges. It is done in connection with evidentiary errors as well as constitutional violations under the respective harmless error doctrines. No such claim can be made for a court's ability to ascertain competence.

s3 These are the Fourth Circuit, see Coles v. Peyton, 389 F.2d 224 (4th Cir. 1968) (counsel must perform specified duties; breach requires new trial subject to rebuttal by showing of harmless error), cert. denied, 393 U.S. 849 (1969), the Sixth Circuit, see Beasley v. United States, 491 F.2d 687 (6th Cir. 1974) (automatic reversal upon finding counsel ineffective), and Pennsylvania, see Commonwealth v. Badger, $482 \mathrm{~Pa}$. 240, 393 A.2d 642 (1978) (defendant need not show prejudice once ineffectiveness is established).

Panel decisions adopting this approach have been overruled by two other circuits sitting en banc, but only over vigorous dissents. See United States v. Decoster, 624 F.2d 196 (D.C. Cir. 1979) (en banc), rev'g 487 F.2d 1197 (D.C. Cir. 1973); Cooper v. Fitzharris, 586 F.2d 1325 (9th Cir. 1978) (en banc), rev'g 551 F.2d 1162 (9th Cir. 1977), cert. denied, 440 U.S. 974 (1979). 
part. ${ }^{84}$ The abstract competence approach departs from the prejudicial incompetence approach by rejecting the notion that the sixth amendment right to competent counsel is qualified by a prejudice requirement. ${ }^{85}$ Under the abstract competence approach, a new trial is ordinarily required once incompetence is shown. ${ }^{86}$ The right to competent counsel is thus regarded as an unconditional guarantee of competence by the sixth amendment. ${ }^{87}$ Generally speaking, the nature of the competence inquiry used by courts that adopt the abstract competence approach differs from that of courts using the prejudicial incompetence approach. Whereas the prejudicial incompetence approach usually focuses on counsel's overall competence, courts adopting the abstract competence approach frequently define competence in terms of a list of specific duties owed by defense counsel to the defendant. ${ }^{88}$ Trial courts are expected to

st See, e.g., Lasater, The Role of Harm in Ineffective Assistance of Counsel Cases: Practice and Policy, 32 SyRAcuSE L. REv. 759, 791-800 (1981); Ineffective Representation as a Basis for Relief from Conviction: Principles for Appellate Review, 13 Colum. J.L. \& Soc. Pross. 1, 48-53, 71-87 (1977); Comment, United States v. Decoster-An Alternative Approach for Reviewing Claims of Ineffective Assistance of Counsel in the D.C. Circuit, 68 GEo. L.J. 1261, 1273-82 (1980); Note, Identifying and Remedying Ineffective Assistance of Criminal Defense Counsel: A New Look After United States v. Decoster, 93 Harv. L. Rev. 752, 763-72 (1980).

os United States v. Decoster, 624 F.2d 196, 275 (D.C. Cir. 1979) (en banc) (Bazelon, J., dissenting) ("The heart of this approach lies in defining ineffective assistance in terms of the quality of counsel's performance, rather than looking to the effects of counsel's actions on the outcome of the case."); see Beasley v. United States, 491 F.2d 687, 696 (6th Cir. 1979); Coles v. Peyton, 389 F.2d 224, 226 (4th Cir. 1968), cert. denied, 393 U.S. 849 (1969).

Bs See United States v. Decoster, 624 F.2d 196, 275-95 (D.C. Cir. 1979) (en banc) (Bazelon, J., dissenting); Beasley v. United States, 491 F.2d 687, 696 (6th Cir. 1974); Coles v. Peyton, 389 F.2d 224, 226 (4th Cir. 1968), cert. denied, 393 U.S. 849 (1969).

87 This unqualified guarantee is occasionally diluted by subjecting it to harmless error rebuttal. Compare. United States v. Decoster, 624 F.2d 196, 293-94 (D.C. Cir. 1979) (en banc) (Bazelon, J., dissenting) (harmless error rebuttal allowed) with Cooper v. Fitzharris, 551 F.2d 1162, 1164-65 (1977) (harmless error doctrine inapplicable), rev'd, 586 F.2d 1325 (9th Cir. 1978) (en banc), cert. denied, 440 U.S. 974 (1979). Even where the harmless error doctrine is applied, however, counsel's errors are not measured by their effect on the outcome, Decoster, 624 F.2d at 293-94 (Bazelon, J., dissenting), as is the rule where harmless error rebuttal is permitted. Harrington v. California, 395 U.S. 250, 254 (1969) (harmless error means harmless in terms of outcome). Rather, this approach determines whether an error is of a type which can contribute to skewing verdicts generally. See Decoster, 624 F.2d at 277-78 (Bazelon, J., dissenting) (discussing duty to investigate). Thus, diluting the unqualified nature of the approach by permitting harmless error rebuttal does not alter the essentially prophylactic nature of the rule; the state may be required to retry the defendant although his legal guilt remains undoubted.

${ }^{8 s}$ See infra note 90 . These include the duty to investigate the facts, to interview adverse and friendly witnesses, to communicate regularly with the defendant, to conduct pretrial discovery, and to conduct a vigorous trial defense. United States v. Decoster, 624 F.2d 196, 276 \& n.63 (D.C. Cir. 1979) (en banc) (Bazelon, J., dissenting). 
supervise compliance with the enumerated duties; ${ }^{89}$ substantial breach of an enumerated duty constitutes a violation of the sixth amendment right to competent counsel. ${ }^{90}$ The absence of a prejudice requirement fundamentally alters the purpose of the competency inquiry the court must make, and hence the analysis of its desirability.

2. Analysis.

a. Abstract Competence as a Prophylactic Rule. Making incompetence of counsel ground for a new trial without regard for the effect of that incompetence on the verdict turns the right to effective assistance into a prophylactic procedural guarantee. A prophylactic right to counsel who performs competently at trial finds little support in the history or purposes of the sixth amendment or in the general jurisprudence of prophylactic rules. As noted above, neither the original intent of the framers nor subsequent interpretations by the Supreme Court supports a guarantee that counsel perform competently. ${ }^{91}$ The sixth amendment supports no more than the right of an indigent defendant to have appointed counsel who, when appointed, appears able to perform competently.

Requiring the state to guarantee the competent performance of defense counsel gives the state every incentive to assert control over the manner in which counsel conducts each phase of the defense; ${ }^{92}$ that incentive is increased where competence is defined as a checklist of duties. Some advocates of this approach welcome the implication that trial courts should supervise the preparation and presentation of the defense by counsel,,$^{93}$ and find that the sixth amendment requires trial courts to monitor either counsel's com-

ss Id. at 296-98 (Bazelon, J., dissenting).

${ }^{20}$ Id. at 281-82 (Bazelon, J., dissenting). It should be noted that though the most common variants are prejudice with general incompetence and no prejudice with specific incompetence, the prejudice requirement and the choice of general or specific test of competence are completely independent. Removing the prejudice requirement while retaining a general test of competence makes finding a constitutional violation turn solely on the reviewing court's assessment of counsel's competence. E.g., Cooper v. Fitzharris, 551 F.2d 1162, 1166 (1977), rev'd, 586 F.2d 1325 (9th Cir. 1978) (en banc), cert. denied, 440 U.S. 974 (1979). Retaining some form of prejudice requirement but focusing on counsel's performance of specific tasks makes a threshold finding of incompetence far more likely than under a general definition of competence, because the creditable aspects of counsel's performance are not balanced against his specific failures. See e.g., United States ex rel. Lee v. Rowe, 446 F. Supp. 1039, 1045, 1047 (N.D. Il. 1978).

"1 See supra notes 35-69 and accompanying text.

"2 United States v. Decoster, 624 F.2d 196, 208 (D.C. Cir. 1979) (en banc) (plurality opinion), 228-29 (MacKinnon, J., concurring).

"3 Id. at 293 n.145, 297-99 (Bazelon, J., dissenting). 
petence or counsel's compliance with each of the enumerated duties. ${ }^{94}$ Yet such supervision intrudes on the constitutionally protected relationship between attorney and client, and undermines the traditional neutrality of the judge. The sixth amendment contemplates that judge, prosecutor, and defense counsel will serve independent roles in assuring fair trials to criminal defendants. ${ }^{95}$ Specifically enumerated duties have been rejected by most courts precisely because they threaten both counsel's independence and the trial court's neutrality. ${ }^{96}$ The sixth amendment "entitle[s the defendant] to the trial judgment of his counsel, not the tactical opinions of the judge."97

In general, prophylactic rules, such as the one advocated by courts adopting the abstract competence approach, operate to require a new trial whenever a given procedure is denied, without regard to the specific effect of that denial on the fairness of the trial. Such rules are not adopted lightly. Usually, the Supreme Court has adopted a prophylactic rule only when the procedural right involved is seen as so indispensable to a fair trial that it is implausible even to assert that a trial in which that right was violated was fair; the rule must involve a matter so fundamental that specific inquiries into the effect in any given case are superfluous. ${ }^{98}$ In addition, the Court usually adopts a prophylactic rule only after observing a pattern of abuse in the state courts that demonstrates the necessity for a uniform, federally enforced rule. ${ }^{99}$ The right to

24 The penalty for failure to comply is a new trial, subject to variations with regard to the role of the harmless error doctrine, see supra notes 86-87, and to certain exceptions for insubstantial or excusable breach, see United States v. Decoster, 624 F.2d 196, 281-82 (D.C. Cir. 1979) (en banc) (Bazelon, J., dissenting).

${ }^{\text {os }}$ Cf. Escobedo v. Illinois, 378 U.S. 478 (1964) (sixth amendment contemplates independent, adversary positions for state and defendant that mandate that state and defendant be to some extent isolated from one another); Massiah v. United States, 377 U.S. 201 (1964) (same). In recognition of this need for independence, some constitutional protection has been extended to the attorney-client relationship even in civil cases. See Maness v. Myers, 419 U.S. 449, 467-68 (1975); id. at 472 (Stewart, J., concurring).

- See United States v. Decoster 624 F.2d 196, 208 \& n.77 (D.C. Cir. 1979) (en banc) (plurality opinion), 228-29 (MacKinnon, J., concurring).

of Id. at 229 (MacKinnon, J., concurring) (quoting Mitchell v. United States, 259 F.2d 787, 793 (D.C. Cir.), cert. denied, 358 U.S. 850 (1958)).

${ }^{8}$ See, e.g., Duncan v. Louisiana, 391 U.S. 145 (1968) (right to trial by jury); Brady v. Maryland, 373 U.S. 83 (1963) (right to production of exculpatory evidence); Gideon v. Wainwright, 372 U.S. 335 (1963) (right to assistance of counsel); see also Illinois v. Allen, 397 U.S. 337 (1970) (sixth amendment right of defendant to be present is not so absolute as to justify a prophylactic rule); Smith v. Illinois, 390 U.S. 129 (1968) (same for right to crossexamination).

" See, e.g., Miranda v. Arizona, 384 U.S. 436 (1966) (pre-trial interrogation); Gideon v. Wainwright, 372 U.S. 335 (1963) (right to assistance of counsel); Mapp v. Ohio, 367 U.S. 643 
competent counsel meets neither of these requirements for prophylactic rules. It has never been seriously contended that "competent" counsel is "a procedure ... necessary to an Anglo-American regime of ordered liberty."100 The Supreme Court does not even regard the appointment of counsel, much less an assurance of his effectiveness, as indispensable to a fair trial in every case. ${ }^{101} \mathrm{Fi}$ nally, there has been no showing of a pattern of abuse in the state courts justifying such an absolute rule.

b. Costs of the Abstract Competence Approach. Unlike the right to have counsel appointed, ${ }^{102}$ an unconditional rule requiring the state to assure that counsel is effective unfairly burdens the state. The state has virtually no control over a non-indigent defendant's choice of retained counsel, and very little control over the actual performance of counsel whether appointed or retained. The state cannot always reliably determine in advance that counsel will prove competent, nor can a reviewing court be confident that it has correctly determined that counsel was incompetent. Thus the state may therefore be punished for an error largely outside its control, although that error may have had no bearing on the reliability of

(1961) (exclusionary rule for fourth amendment violations); Brown v. Mississippi, 297 U.S. 278 (1936) (new trial for coerced confessions); see also Argersinger v. Hamlin, 407 U.S. 25, 65 (1972) (Powell, J., concurring) (noting that Gideon was a response to failure of state courts to appoint counsel at appropriate times); Friendly, The Bill of Rights as a Code of Criminal Procedure, 53 CALIF. L. REv. 929, 950 (1965) (arguing that the Court should continue to limit the development of prophylactic rules to deterrence of undesirable state misconduct and not allow enforcement of affirmative behavior); Packer, The Courts, The Police, and the Rest of Us, 57 J. Crim. L. Criminology \& Pol. Scr. 238, 239 (1966) (discussing how a pattern of state abuse leads the Court to develop prophylactic rules).

${ }^{100}$ Duncan v. Louisiana, 391 U.S. 145, $150 \mathrm{n} .14$ (1968). This is not to say that a criminal defendant has no claim when counsel is ineffective. It is merely to note that this claim is subsumed under his more general claim to a fair and reliable trial. See infra notes 138-77 and accompanying text. Thus, as a procedural right, the right to counsel who is competent and effective is not so fundamental as to require protection other than freedom from the prejudicial effects of any errors by counsel at the defendant's trial. See id.

${ }^{101}$ See Scott v. Illinois, 440 U.S. 367, 369-74 (1979) (sixth amendment does not require state to appoint counsel for a criminal defendant charged with a statutory offense for which imprisonment is authorized but not imposed); cf. Argersinger v. Hamlin, 407 U.S. 25, 36-37 (1972) (declining to require that counsel be appointed for criminal charges not leading to imprisonment).

102 It is clearly within the state's power to control the appointment of counsel to indigent defendants. Even in the absence of state-created public defender services, the common law powers of courts to compel attorney service are well established. See Powell v. Alabama, 287 U.S. 45, 73 (1932); Schwarzer, Dealing With Incompetent Counsel-The Trial Judge's Role, 93 Harv. L. REv. 633, 635 n.12 (1980). Compliance by the state can, moreover, be readily ascertained, ensuring that the state will know when it has fulfilled its obligations, and that it will be "penalized" by a reviewing court only when it in fact has not fulfilled them. The same cannot be true of a prophylactic rule which guarantees "competence." See infra notes 103-20 and accompanying text. 
the defendant's conviction.

Competence and effectiveness are not susceptible of precise definition. Errors by counsel labeled "incompetence" will often not involve a clearly measurable procedural irregularity; yet under the abstract competence approach, a new trial is required whenever a reviewing court determines that counsel has been "incompetent." This outcome exalts a guarantee that can only constructively be called procedural fairness over state interests in the finality and the reliability of a verdict. The distortion of the balance among finality, reliability, and procedural fairness is apparent in the unequal treatment accorded defendants whose counsel is marginally competent and those whose counsel is marginally incompetent. The former are likely to have no means of obtaining relief, even from outcome-determinative error, given the operation of state procedural default rules and the reluctance of appellate courts to look beyond the trial record. ${ }^{103}$ The latter receive new trials even where their underlying claims involve errors which are neither specifically constitutional nor outcome-determinative. ${ }^{104}$

In addition, no reason exists to assume that trial court supervision will produce superior results. Much attorney incompetence is caused not by poor skills or indifference but by inadequate time and undercompensation. ${ }^{105}$ Overwork and undercompensation, however, afflict the bench as well as the bar. "Incompetence" of this variety reasonably can be expected to handicap many judges as well as lawyers in the performance of their duties. Indeed, there is some reason to fear that burdening trial courts with an all-inclusive duty to supervise defense counsel will increase the incidence of judicial incompetence in the performance of traditional judicial tasks. Trial court supervision would without doubt lead to better performance by counsel and hence to speedier and less disruptive trials in some cases. ${ }^{108}$ But this potential is a reason for leaving the choice and form of trial court supervision "to the good sense and discretion of the trial courts," ${ }^{102}$ rather than for constitutionalizing a rule or set of rules requiring judges to spend scarce judicial time in every case. ${ }^{108}$ Moreover, not all judges are free from the indiffertext.

${ }^{103}$ See supra notes 7-8 and accompanying text; infra notes 179-82 and accompanying

${ }^{104}$ See supra notes 4-6, 9-11 and accompanying text.

${ }^{103}$ See Comment, supra note 77, at 996-97 \& n.102.

106 See Schwarzer, supra note 102, at 665 .

107 McMann v. Richardson, 397 U.S. 759, 771 (1970).

10 This comment does not mean to condemn policy decisions by courts or legislators that judges should intervene where counsel's performance is seriously ineffective; it merely 
ence to defendants' rights or the lack of professional skill that some defense attorneys display. To require such judges to supervise defense counsel is to make a bad situation worse; the sixth amendment wisely requires that the defendant not be exposed to this hazard.

Requiring counsel to perform enumerated duties in every case also interferes with counsel's ability to use the limited time and resources at his disposal to the best effect. ${ }^{100}$ Such a requirement would encourage counsel to protect himself by going through the motions of formal compliance rather than protect the defendant by focusing on the areas where counsel's help is most likely to be useful. The abstract competence approach is as likely to increase the incidence of incompetent counsel as it is to reduce it, and, in any event, is likely to create undesirable incentives for both court and counsel.

c. Impact on Post-Conviction Remedies and Default Rules. Over and above the constitutional and policy difficulties that beset the abstract competence approach are its potentially devastating implications for the administration of post-conviction remedies and state procedural default rules. ${ }^{110}$ Although practices vary from state to state, most state appellate and collateral attack courts grant new trials for nonconstitutional error only upon a showing of outcome-determinative prejudice. ${ }^{111}$ The abstract competence approach, however, requires no such showing; its definition of competence permits-perhaps even requires-that counsel's failure to

asserts that the sixth amendment does not require such intervention. Judge Schwarzer has presented guidelines for intervention designed to forestall incompetence without requiring the judge to conduct the defense. See Schwarzer, supra note 102, at 661-65 (intervention at trial), 651-58 (pre-trial monitoring), 659-60 (pre-trial intervention). Such efforts deserve to be tried, but to claim that the sixth amendment requires such monitoring and supervision of defense counsel's actual performance is to assume much of what such experiments are intended to confirm or disprove. Judge Schwarzer does not argue that his guidelines are required by the sixth amendment; indeed, he suggests that the sixth amendment places limits on the judge's authority to regulate the defense. Id. at 636-39 \& n.20, 661-62. This comment argues that similarly effective but less intrusive forms of regulation have been overlooked. See infra notes 207-15 and accompanying text. The safeguards proposed below are intended to minimize the conditions that result in ineffective representation without requiring the trial judge to monitor the actual performance of counsel.

${ }_{10} \mathrm{Cf}$. Jones v. Barnes, $103 \mathrm{~S}$. Ct. 3308, 3314 (1983) (For judges to second-guess judgments by counsel as to which of defendant's colorable claims should be raised on appeal "would disserve the very goal of vigorous and effective advocacy.").

110 For a discussion of the impact of this comment's proposal on this body of law, see infra notes 216-26 and accompanying text.

111 See Chapman v. California, 386 U.S. 18, 22, 23 \& n.7 (1967) (noting that all 50 states have harmless error rules and indicating that the state court in that case had construed the state harmless error statute to require a showing of error that affected the outcome). 
raise a claim that might have been meritorious be held to constitute incompetence. ${ }^{112}$ The defendant can deliberately bypass state remedies, even for state law claims, by recasting the underlying substantive claim as a "procedural" constitutional defect: incompetence of counsel. ${ }^{113}$ Defendants may thereby obtain new trials for underlying non-constitutional claims through the federal courts without having to show the prejudice required by the state courts for relief on those claims. Indeed, given the favorable standard of review this approach seems to employ, ${ }^{114}$ defendants have powerful incentives to do exactly that, which is hardly a desirable result for relations between state and federal courts.

The abstract competence approach also threatens to transform radically, in both manner and stringency, the review of defaulted constitutional claims. Under Wainwright $v$. Sykes, ${ }^{118}$ a defendant can obtain collateral review of such claims only by showing both cause for the default ${ }^{116}$ and actual prejudice from the default to the outcome of his trial. ${ }^{117}$ The same defaulted claim is subject to independent and generally stringent review if presented as an incompetent counsel claim under the abstract competence approach. In some cases incompetence at trial will prove to be a more difficult showing than cause for default. However, procedural default of a colorable constitutional claim strongly implies incompetence, ${ }^{118}$ and incompetence is itself cause for such a default. ${ }^{119}$ Furthermore,

112 See United States v. Decoster, 624 F.2d 196, 276 n.63 (D.C. Cir. 1979) (en banc) (Bazelon, J., dissenting) (counsel should take all actions necessary to protect defendant's rights). Judge Bazelon does suggest that claims such as failure to object to inadmissible evidence could be subject to harmless error rebuttal, id. at 294 , but since he rejects any requirement of outcome-determinativeness, $i d$. at $291 \mathrm{n} .136$, such claims are still easier to maintain as incompetent-counsel claims under the abstract competence approach than as collateral-attack claims under state law. See supra notes 115-20 and accompanying text.

11 This can be done with great ease and with virtually any claim. See, e.g., supra notes 8-9 and accompanying text.

114 See supra notes $115-20$ and accompanying text.

115433 U.S. 72 (1977).

118 Id. at $87,90-91$.

${ }^{117}$ Id. at 87, 91. Actual prejudice undoubtedly requires some showing of outcome determinativeness. See United States v. Frady, 456 U.S. 152 (1982). In Frady, the Supreme Court indicated that a showing of "actual prejudice" was greater than a showing of plain error on appeal. Id. at 166 (quoting Henderson v. Kibbe, 431 U.S. 145, 154 (1977)). The formulation of actual prejudice adopted by the Court strongly suggests that a colorable claim going to legal guilt (i.e., an outcome-determinative claim) is required, at least implicitly, for establishing actual prejudice. See id. at 172-74.

${ }^{118}$ See supra note 112 and accompanying text.

119 In Runnels v. Hess, 653 F.2d 1359 (10th Cir. 1981), the court held that erroneous decisions by counsel, even if "short of that necessary to make out a Sixth Amendment claim," may constitute cause for a procedural default. Id. at 1364; cf. Indiviglio v. United States, 612 F.2d 624, 631 \& n.13 (2d Cir. 1979) (reserving the issue but implying that such 
a showing of such a default will, in most cases, constitute a sufficient showing of incompetence to satisfy the abstract competence approach. Once incompetence is established under that approach, the defendant need not show prejudice to prevail on his claim and receive a new trial. Thus, the availability of an incompetent counsel claim under the abstract competence approach can nullify completely the actual prejudice requirement for collateral attack imposed by Sykes. ${ }^{120}$

If both traditional habeas and abstract competence review are available to defendants, state law claims as well as procedurally defaulted constitutional claims will be reviewable under two significantly dissimilar procedures and standards. In the case of state law claims, this proliferation of modes of review undermines the state's interest in the enforcement of its procedural rules in cases involving its substantive law, the class of claims where that interest is strongest. In the case of defaulted constitutional claims, it accords disparate treatment to defendants raising essentially identical claims on the basis of a very inexact assessment of attorney competence.

Analysis of the sixth amendment, and of the current approaches to the right to competent counsel based on it, demonstrates several significant points. First, as a matter purely of historical authority and subsequent Supreme Court interpretation, there is only a limited "right to competent counsel" in the sixth amendment. The language and history of the sixth amendment, and, most importantly, existing precedent support no more than

incompetence constitutes cause), cert. denied, 445 U.S. 933 (1980).

${ }^{130}$ These objections apply with fullest force where failure by counsel to perform specific duties is deemed sufficient to establish a sixth amendment violation. To a considerable extent, however, they apply to any approach to incompetent counsel claims which requires less than "actual prejudice" for procedurally defaulted constitutional claims. See supra notes 88-90 and accompanying text.

The abstract competence approach as applied to procedurally defaulted fourth amendment claims is also inconsistent with the Supreme Court's holding in Stone v. Powell, 428 U.S. 465 (1976). Stone held habeas corpus relief unavailable for fourth amendment claims where there was "an opportunity for full and fair litigation" in the state court. Id. at 494. Under either sixth amendment approach to incompetent counsel claims, a defendant could easily escape the strictures of Stone by bringing fourth amendment claims as incompetent counsel claims in habeas proceedings. Under the abstract competence approach, for example, any fourth amendment claim that counsel failed to raise and that might have resulted in the suppression of evidence would require a new trial so long as the suppression would have been helpful to the defense. At least one commentator finds this state of affairs a happy one. See Note, Stone-v. Powell and the Effective Assistance of Counsel, $80 \mathrm{MrcH}$. L. REv. 1326 (1982) (arguing for relief on sixth amendment grounds even where the sole underlying claim is based on the exclusionary rule). 
the right of an indigent defendant to have counsel appointed, though, as we shall see below, ${ }^{121}$ that right may be interpreted to provide a significant guarantee of counsel's apparent competence at the time of appointment. Second, as a matter of policy, approaches that oblige the court to inquire into the actual competency of counsel at trial have little to commend themselves. Incompetency inquiries are difficult, unclear, and run counter to the sixth amendment notion of opposing, independent adversaries. Constitutionally required trial-court supervision of counsel therefore seems undesirable. Finally, definitions of the right that give dispositive effect to a finding of incompetence circumvent federal habeas limitations and thwart state interests in procedural default rules.

\section{The Fair Trial Guaranteg Approach}

\section{A. Description}

One federal court of appeals ${ }^{122}$ and many state courts ${ }^{123}$ still adhere to the "fair trial guarantee" approach, which, until some ten years ago, was employed by nearly all state and federal courts. ${ }^{124}$ Under this approach, a defendant who attacks only the quality of his counsel's performance fails to state a sixth amendment claim. ${ }^{125}$ Instead, the courts require the defendant to establish that, because of counsel's incompetence, the defendant was denied a fair trial, in violation of due process of law. ${ }^{126}$ The principal doctrinal issue under this approach is the scope and content of the fair trial guarantee. Two variations are encountered.

The older variation, still employed by some courts, ${ }^{127}$ obliges the defendant to show that "the proceedings were a farce and a

121 See infra notes 188-94 and accompanying text.

${ }^{122}$ See United States v. Bubar, 567 F.2d 192, 202 (2d Cir.), cert. denied, 434 U.S. 872 (1977). But cf. Indiviglio v. United States, 612 F.2d 624, 629 n.8 (2d Cir. 1979) (indicating it might reconsider this test in an appropriate case), cert. denied, 445 U.S. 933 (1980).

${ }_{123}$ See Annot, 2 A.L.R. 4TH 27, 99-108 (1980) (collecting cases).

134 See Bines, supra note 72 , at 928.

${ }^{125}$ E.g., Diggs v. Welch, 148 F.2d 667, 668 (D.C. Cir.), cert. denied, 325 U.S. 889 (1945). These courts define the scope of the sixth amendment right to competent counsel in the same manner as this comment: a duty to safeguard defendant's right to appointed counsel by appointing counsel who appears competent at the time of appointment. See, e.g., Diggs, 148 F.2d at 668. Having posited the existence of a right, however, they fail to provide for its enforcement. See infra notes $185-88$ and accompanying text.

${ }^{128}$ Diggs v. Welch, 148 F.2d 667, 669 (D.C. Cir.), cert. denied, 325 U.S. 889 (1945).

${ }^{127}$ See, e.g., id.; Hoover v. State, 270 Ark. 978, 980, 606 S.W.2d 749, 751 (1980); Line v. State, 273 Ind. 227, 229, 397 N.E.2d 975, 976 (1979). 
mockery of justice."128 The "farce and mockery" test treats counsel's incompetence as an "evidentiary fact" in the reviewing court's inquiry into "the presence or absence of judicial character in the proceedings as a whole."129 Even mistakes by counsel that might have altered the guilty verdict will not, standing alone, suffice to establish denial of a fair trial. ${ }^{130}$ In this view, the fair trial guarantee is exclusively procedural; a new trial is granted only if procedural defects in the trial as a whole amount to a denial of "fundamental fairness." "1s1

Most courts that adopt the fair trial guarantee approach have moved away from the harshness of the "farce and mockery" test. 132 They interpret the fair trial guarantee to encompass the reliability of the verdict as an implicit element of a fair trial. The defendant need not show that counsel utterly failed to represent him, only that counsel's mistakes probably affected the outcome of defendant's trial, and hence cast doubt upon his legal guilt. ${ }^{13 s}$

In addition to showing outcome-determinative prejudice, defendants under either of these versions of the fair trial guarantee approach are commonly required to attack counsel's competence on the record. If counsel appears on the record to have defended his client with any vigor, many courts will refuse to consider specific errors or matters outside the record on the ground that the defendant plainly received a fair trial. ${ }^{134}$ Even if counsel competence is not evident from the record, some courts confine a defendant to the trial record on appeal, despite the potential for claims relating to counsel's pre-trial performance ${ }^{185}$ or to evidence not in the record. ${ }^{138}$

Courts that adopt sixth amendment analyses of competent counsel problems do not dispute the applicability of this approach.

12. Diggs v. Welch, 148 F.2d 667, 669 (D.C. Cir.), cert. denied, 325 U.S. 889 (1945).

139 Id. at 669,670 .

${ }^{120}$ Id. at 670. The Diggs court based this holding in part, upon its claim that "[h]ow much [counsel's] mistakes contributed to the result can never be measured." Id.

${ }^{231}$ Id.; cf. Waltz, supra note 54, at 305.

${ }^{232}$ See Waltz, supra note 54, at 304-05; Note, The Effective Assistance of Counsel: An Incomplete Constitutional Right, $18 \mathrm{ME}$. L. REv. 248, 263 (1966).

${ }_{12 s}$ See, e.g., People v. Dudley, 46 III. 2d 305, 308, 263 N.E.2d 1, 3, cert. denied, 402 U.S. 910 (1970); Schoonover v. State, 2 Kan. App. 2d 481, 493, 582 P.2d 292, 299 (1978).

134 See, e.g., People v. Lee, 43 IIl. App. 3d 807, 812, 357 N.E.2d 652, 656 (1976). In subsequent habeas proceedings, the federal district court in Illinois criticized the state court's reliance on the trial record. United States $e x$ rel. Lee v. Rowe, 446 F. Supp. 1039, 1044, 1047 (N.D. IIl. 1978).

1ss See, e.g., People v. Jackson, 41 Ill. App. 3d 816, 822, 354 N.E.2d 643, 647 (1976);

Winter v. State, 210 Kan. 597, 601, 604, 502 P.2d 733, 737, 739 (1972).

126 See, e.g., United States ex rel. Feeley v. Ragen, 166 F.2d 976, 980 (7th Cir. 1948). 
Rather, they tend to consider it superseded by the "overlapping but more stringent" requirements of the sixth amendment. ${ }^{137}$ One reason for this conclusion may well be a lack of understanding as to the scope and content of the protection provided by the fair trial guarantee, in particular, the extent to which it protects defendants from outcome-determinative errors on the part of counsel. The next section will show that the fair trial guarantee protects the defendant whenever the conduct of his counsel calls into question his guilt beyond a reasonable doubt.

\section{B. Analysis}

That due process of law guarantees criminal defendants a "fair trial" has been clear at least since Powell $v$. Alabama, ${ }^{138}$ where the Supreme Court held that it is "the duty of the court . . . to see that [the defendants] were denied no necessary incident of a fair trial."139 The Supreme Court has developed a model of a fair trial that the due process clause of the fourteenth amendment makes binding on the states. This model emphasizes both procedural fairness and substantive reliability. Thus, on occasion the Court has incorporated rights included in the Bill of Rights because it regards them as necessary to a procedurally fair trial, even where the condemned unfairness on the state's part contributes positively to the reliability of the verdict appealed from or of verdicts generally; ${ }^{140}$ in other cases, the Court has viewed specific rights as incorporated in due process because those rights serve to create the conditions for a reliable verdict. ${ }^{141}$

The fair trial guarantee is a subcategory of due process. ${ }^{142}$ The

${ }^{137}$ Scott v. United States, 427 F.2d 609, 610 (D.C. Cir. 1970).

138287 U.S. 45 (1932).

139 Id. at 52 .

${ }^{140}$ E.g., Miranda v. Arizona, 384 U.S. 436 (1966) (exclusionary rule for illegally obtained confessions); Mapp v. Ohio, 367 U.S. 643 (1961) (same for illegally obtained evidence).

${ }^{141}$ E.g., Pointer v. Texas, 380 U.S. 400, 404 (1965) (confrontation clause); Douglas v. Alabama, 380 U.S. 415, 418-19 (1965) (same); see also Roberts v. Russell, 392 U.S. 293, 295 (1968) (per curiam) (applying confrontation clause decisions retroactively because "the constitutional error presents a serious risk that the issue of guilt or innocence may not have been reliably determined").

${ }^{142}$ The court has often spoken of due process as a guarantee of "fundamental fairness," e.g., Duncan v. Louisiana, 391 U.S. 145, 172 (1968) (Harlan, J., dissenting); Betts v. Brady, 316 U.S. 455 (1942), overruled, Gideon v. Wainwright, 372 U.S. 335 (1963), or "fundamental rights," e.g., Duncan v. Louisiana, 391 U.S. 145, 154 (1968); Gideon v. Wainwright, 372 U.S. 335 (1963). This guarantee has led to the incorporation into the due process clause of certain rights, such as the fourth amendment right to freedom from unreasonable searches and seizures, see Wolf v. Colorado, 338 U.S. 25, 27-28 (1949), that evince a more general concern 
fair trial guarantee narrows the general due process inquiry into "fundamental fairness" by focusing on fairness in the context of an adversary factfinding proceeding. The Supreme Court has elaborated the attributes that a fair and reliable trial must possess, thereby making it possible to identify specific violations of the fair trial guarantee. ${ }^{143}$ Many such violations trigger specific rights imported from the Bill of Rights. ${ }^{144}$ The present inquiry concerns a second category-violations of specific rights inherent in the fair trial guarantee itself. ${ }^{145}$ In this, its purest manifestation, the fair trial guarantee embodies an element of substantive due process.

Powell v. Alabama ${ }^{146}$ clearly demonstrates this concern with the substantive fairness of the trial and the reliability of the verdict. The defendants' convictions in that case were obtained under extremely suspect conditions. ${ }^{147}$ In particular, the trial court, though required by state law to appoint counsel, did so in such a manner as to preclude the defendants from receiving any real aid from counsel.148 Several alternative grounds for reversing were available to the Supreme Court: the Court could have reexamined the state court findings that the appointment did not violate state law; it could have incorporated the sixth amendment right to counsel into the due process clause; or it could simply have declared the trial to have been, on the whole, a "farce and mockery."149 The

with the proper balance between state power and individual liberty.

is The fair trial guarantee does not encompass the more pervasive kinds of unfairness that may inhere in particular circumstances surrounding the trial. Such unfairness still falls within the purview of the due process clause. E.g., Rochin v. California, 342 U.S. 165 (1952) (due process includes the right not to have evidence obtained by forcible stomach pumping).

14 E.g., Klopfer v. North Carolina, 386 U.S. 213 (1967) (right to a speedy trial); In re Oliver, 333 U.S. 257 (1948) (right to public trial); see Duncan v. Louisiana, 391 U.S. 145, 148 (1968) (collecting cases).

${ }^{145}$ E.g., United States v. Agurs, 427 U.S. 97, 109 (1976) (due process requires prosecution to disclose evidence "giving rise to a legitimate doubt on the issue of guilt"); Foster v. California, 394 U.S. 440, 443 (1969) (admission of unreliable eyewitness identification violates due process); Brady v. Maryland, 373 U.S. 83 (1963) (due process right to have prosecution disclose exculpatory evidence).

146287 U.S. 45 (1932).

147 The trial occurred "in an atmosphere of tense, hostile and excited public sentiment." Id. at 51 . The entire process from arraignment to conviction seemed designed to railroad the defendants. See id. at 51-58.

148 First, the trial court appointed the entire bar, charging no one lawyer with the duty of aiding the defendants. In the atmosphere that pervaded the trial it was unlikely that any lawyer would have assumed that duty independently. Id. at 56. A more specific appointment was not made until the time of trial, "within a few moments" of the time defendants were to be "put in peril of their lives." Id. at 58.

14: Several facts made the "farce and mockery" course the simplest. The court apparently accepted allegations by the defendants that their trial was mob-dominated and largely proforma. See supra notes 147-48. The dissent below appears to have come to a similar 


\section{Court chose not to adopt any of these alternatives. ${ }^{150}$}

Instead, the Powell Court derived, from the due process requirements of notice and opportunity to be heard, a right to be heard through retained counsel in all cases, civil or criminal, state or federal. ${ }^{181}$ 'The Court also found, in response to the defendants' inability, as a practical matter, to establish their own innocence, that the due process clause embodies a right to have counsel appointed in capital cases. ${ }^{152}$ Thus, the fair trial guarantee was interpreted as protecting reliable factfinding as well as procedural fairness, and hence serves as an independent source of constitutional protection for criminal defendants in addition to the constitutional rights incorporated into it.153 Our next task is to delineate the scope and form of this protection.

conclusion. Powell v. State, 224 Ala. 540, 554, 141 So. 201, 214 (1932) (Anderson, C.J., dissenting). Finally, precedent supported this conclusion. Moore v. Dempsey, 261 U.S. 86, 91 (1923), and Frank v. Mangum, 237 U.S. 309, 335 (1915), had recognized that "if in fact a trial is dominated by a mob so that there is an actual interference with the course of justice, there is a departure from due process of law . . ." Moore, 261 U.S. at 90-91. Frank had taken a very restrictive view of the power of a federal habeas court to grant relief or to make new factual findings where the state appellate court found no mob domination. See 237 U.S. at 335, 336. The Moore Court, however, both broadened the scope of federal habeas review, see 261 U.S. at 92 , and suggested that the Supreme Court could find the fact of mob domination itself:

[I]f the case is that the whole proceeding is a mask-that counsel, jury and judge were swept to the fatal end by an irresistible wave of public passion, and that the State Courts failed to correct the wrong, neither perfection in the machinery for correction nor the possibility that the trial court and counsel saw no other way of avoiding an immediate outbreak of the mob can prevent this Court from securing to the petitioners their constitutional rights.

Id. at 91 .

${ }^{160} 287$ U.S. at $50,51,52,66,67-68$. Despite claims that each of these rights was violated, the Powell Court expressly confined its inquiry to the defendants' claims concerning denial of counsel as a violation of due process. Id. at $\mathbf{5 0 .}$

${ }^{202}$ Id. at 69. This conclusion does not rely even implicitly on the sixth amendment, which is expressly limited to "all criminal prosecutions." U.S. CoNST. amend. VI.

162287 U.S. at 72. The Powell Court expressly limited its holding to the facts of the case before it, id. at 71, but as the Court's later decisions show, that limitation does not apply to the principles enunciated in Powell. See Gideon v. Wainwright, 372 U.S. 335, 343 (1963) (applying the right to counsel to the states in all felony cases in part on the basis of Powell's "unmistakable" recognition of "the fundamental nature of the right to counsel"). Similarly, though the Court buttressed its interpretation of the fair trial guarantee by reference to the practice in most states of appointing counsel in capital cases, the validity of its reasoning is independent of both state practice and the sixth amendment. See 287 U.S. at 73. Indeed, at the time Powell announced a limited right to appointed counsel under the rubric of the fair trial guarantee, it would still be six years before the sixth amendment was interpreted to include any right to have counsel appointed, even in capital cases. See Johnson v. Zerbst, 304 U.S. 458 (1938).

163 The substantive aspect of the fair trial guarantee is vividly illustrated by the opinions of Justice Black, principal architect of the Court's interpretations of the sixth amendment and the right to have counsel appointed. Six years after Powell, Justice Black held for the Court in Johnson v. Zerbst, 304 U.S. 458 (1938), that the right to counsel clause requires 
One view of the fair trial guarantee was announced by the District of Columbia Circuit in 1945 in Diggs $v$. Welch. ${ }^{154}$ The Diggs court held that attacks on the quality of counsel's performance would merit relief only when the defendant was able to show that his trial was fundamentally unfair. ${ }^{185}$ A trial is fundamentally unfair, the court announced, only when, on the whole, it is a sham, a "farce and mockery" of justice. ${ }^{156}$ Though incompetence may contribute to making a trial a farce and mockery, standing alone it will rarely be sufficient. In effect, the Diggs holding reduces the fair trial guarantee to a guarantee of procedural regularity; ${ }^{167}$ it does not involve an assessment of the impact of counsel's errors on the reliability of the verdict.

This exclusively procedural interpretation of the fair trial guarantee can fairly be traced to the baleful influence of Betts $v$. Brady. ${ }^{158}$ In Betts, the Court narrowly construed Powell v. Ala-

federal courts, as a condition of depriving a criminal defendant of "life or liberty," to appoint counsel. Id. at 463. He relied, not on text or history, but on the "policy of the modern criminal law" requiring appointment of counsel in serious cases and on Powell's description of the importance of counsel in securing procedural fairness and a reliable verdict for the defendant. Id. (quoting Powell, 287 U.S. at 68-69). The fair trial guarantee as interpreted in Powell served as the principal support for the Court's creation of the sixth amendment right to appointed counsel. Of course, as this line of cases shows, the concern with reliability present in the fair trial guarantee may lead to the adoption of a specific procedural right on the ground that the procedure is necessary if reliability is to be preserved. It does not follow that the substantive aspect of the fair trial guarantee must always require that a procedure be applied categorically to certain classes of cases.

Furthermore, both in his opinion in Gideon v. Wainwright, 372 U.S. 335 (1963), and in his dissent in Betts v. Brady, 316 U.S. 455 (1942), overruled in Gideon, 372 U.S. at 342, Justice Black argued, along with his usual argument for incorporation, that the fair trial guarantee, as interpreted in Powell, requires extension of the right to appointed counsel to indigent felony defendants. In Betts, Justice Black quoted Powell on the importance of counsel to a fair trial and argued that a trial is not fair unless it is possible "to conclude, with [a] satisfactory degree of certainty, that the defendant's case was adequately presented." 316 U.S. at 475-76 (quoting Powell, 287 U.S. at 68-69). In Gideon, Justice Black once again quoted Powell on the need for counsel, and held that "in our adversary system of criminal justice, any person . . . who is too poor to hire a lawyer[] cannot be assured a fair trial unless counsel is provided for him." 372 U.S. at 344. The fair trial guarantee is used in these cases in two distinct ways: as the vehicle for incorporating the sixth amendment into the due process clause, and, more to the point for present purposes, as an independent source of support for the right to appointed counsel.

164148 F.2d 667 (D.C. Cir.), cert. denied, 325 U.S. 889 (1945).

138 Id. at 669 .

1se Id. at 669-70.

${ }^{257}$ See Mitchell v. United States, 259 F.2d 787, 790 (D.C. Cir.) (effective assistance of counsel is "a procedural requirement, as contrasted with a standard of skill"), cert. denied, 358 U.S. 850 (1958).

158316 U.S. 455 (1942) overruled, Gideon v. Wainwright, 372 U.S. 335, 342 (1963). 
bama, mistakenly treating it as resting on a state-created right to appointed counsel. ${ }^{159}$ Betts created a presumption that compliance with state law satisfies due process unless the trial itself was a sham, and hence invalid. ${ }^{180} \mathrm{~A}$ defendant could overcome the presumption of a fair trial only by showing either that the trial was a travesty, or that special circumstances made a particular procedure fundamentally unfair as applied to him. ${ }^{161}$

Betts was overruled by Gideon $v$. Wainwright, ${ }^{162}$ which revived the earlier view of the fair trial guarantee expressed in Powell itself. ${ }^{163}$ As previously noted, this view of the fair trial guarantee seeks not only to insure procedural fairness, but also to protect the reliability of the verdict. ${ }^{164}$ Actions of an attorney that fall short of calling the fairness of the trial as a whole into question may still impugn the reliability of the verdict and in this way amount to a denial of due process. The "farce and mockery" standard adopted by Diggs ignores reliability entirely; as a consequence, at least since the Supreme Court revived the Powell interpretation of the fair trial guarantee in Gideon, this standard has been inconsistent with prevailing law. The question still remaining is the scope of protection accorded by this reliability aspect of the fair trial guarantee.

In In re Winship, ${ }^{165}$ the Supreme Court, seeking to insure the reliability of verdicts, held that due process requires that criminal defendants be convicted only upon proof beyond a reasonable doubt of every element of the offense charged. ${ }^{166}$ According to the

${ }^{168}$ Id. at 463 . The Betts Court rendered this mistaken interpretation of Powell in spite of a declaration by the Powell Court that it was "powerless to interfere" with the state court's finding of compliance with state law. 287 U.S. at 60.

${ }^{180} 316$ U.S. at 464.

181 Id. at 473. The Betts Court decided that appointment of counsel was not required "in all cases" as a matter of "natural, inherent, and fundamental principles of fairness." Id. at 464 . The Court arrived at this conclusion by examining only the historical and contemporary practice in the states. Id. at 464-71. The Court seems to have reasoned that the general rules constituting due process are presumptively defined by state practice, so that compliance with state law in any particular case constitutes presumptive compliance with due process. Powell had alluded to no such presumptions.

${ }^{182} 372$ U.S. 335,342 (1963).

${ }^{163}$ See supra notes $146-53$ and accompanying text.

164 See supra notes $138-53$ and accompanying text.

185397 U.S. 358 (1970).

${ }^{168}$ Id. at $362-64$. The Court repeatedly refers to the fundamental importance of the reasonable doubt standard to the American scheme of justice and argues that "[i]t is a prime instrument for reducing the risk of convictions resting on factual error." Id. at 363. The Court concludes:

It is critical that the moral force of the criminal law not be diluted by a standard of proof that leaves people in doubt whether innocent men are being condemned. It is 
Court in Jackson $v$. Virginia, ${ }^{167}$ the Winship holding means that "no person shall be made to suffer the onus of a criminal conviction except upon sufficient proof-defined as evidence necessary to convince a trier of fact beyond a reasonable doubt of every element of the offense."168 If the defendant can demonstrate on appeal that any rational factfinder would have entertained a reasonable doubt about the conviction, that conviction violates due process and cannot stand. ${ }^{169}$

United States $v$. Agurs ${ }^{170}$ illustrates the proper application of this due process standard for a reliable verdict. In Agurs, a murder trial in which the defendant pleaded self-defense, the prosecution failed to disclose to the defense that the victim had a prior criminal record of assault and carrying a deadly weapon. Agurs thus obliged the Court to define the scope of the defendant's right to have the state disclose exculpatory evidence. ${ }^{171}$ Whether this failure to disclose is sufficiently material to constitute a violation of due process, the Court held, depends upon the standard of materiality used. ${ }^{172}$ The Court specifically rejected a standard that focuses on preparation of an effective defense "rather than [on] the materiality of the evidence to the issue of guilt or innocence."17s The court concluded:

The proper standard of materiality must reflect our overriding concern with the justice of the finding of guilt. Such a finding is permissible only if supported by evidence establishing guilt beyond a reasonable doubt. It necessarily follows that if the omitted evidence creates a reasonable doubt that did not otherwise exist, constitutional error has been committed. ${ }^{174}$

also important in our free society that every individual going about his ordinary affairs have confidence that his government cannot adjudge him guilty of a criminal offense without convincing a proper factfinder of his guilt . . . .

Id. at 364. The holding, though supported by the Court's invocation of 200 years of practice, seems to rest solely on the concern for reliability of the verdict embodied in the due process clause and first recognized in Powell.

167443 U.S. 307 (1979).

188 Id. at 316.

160 Id. at 316-18.

170427 U.S. 97 (1976).

171 This right of disclosure, an example of a substantive rule supported only by the due process clause that seeks to insure reliable factfinding, see supra note 145 and accompanying text, was first recognized in Brady v. Maryland, 373 U.S. 83, 86-88 (1963).

172427 U.S. at 111-12.

173 Id. at 112 n.20.

174 Id. at 112 (footnote omitted). 
Plainly, under Winship, Jackson, and Agurs, if, but for an attorney's acts or omissions, the factfinder would likely have entertained a reasonable doubt about the defendant's guilt, the state cannot convict the defendant consistently with due process. ${ }^{175}$ The "right to competent counsel" is the right to counsel who does not adversely prejudice the defendant in an outcome-determinative fashion; such a right, by definition, invokes society's interest in convicting defendants only upon proof beyond a reasonable doubt. ${ }^{176}$ Defendants may thus raise claims based upon incompe-

178 Agurs represents a change in formulation of the due process guarantee of a reliable verdict from the Jackson requirement that any reasonable factfinder would have entertained a reasonable doubt, see supra text at notes $167-69$, to a requirement that the actual factfinder would likely have entertained a reasonable doubt. The difference in formulation can be traced to the different contexts in which the standard arose. In Jackson, the issue before the Court was the general quantum of evidence required to overturn a jury verdict of guilty on due process grounds. In Agurs, the Court was called upon to assess the degree of importance of specific suppressed exculpatory evidence, relative to the evidence as a whole, that would require reversal of a conviction on due process grounds. In any event, since a doubt that is reasonable to one reasonable factfinder is very likely reasonable to any reasonable factinder, the distinction between the two formulations is, as a practical matter, far smaller than it appears to be as a theoretical one.

${ }^{176}$ It might be argued that cases such as Agurs involve acts or omissions committed by the prosecutor, i.e., the state, and thus deserve different treatment than those of defense counsel. Outcome-determinative prejudice caused by the state, so the argument goes, is not the same as outcome-determinative prejudice caused by defense counsel. Defendant, not the state, must bear the risk and the consequences of his own counsel's acts. This argument is reminiscent of one justification for the incompetence inquiry of the prejudicial incompetence approach, see supra notes 70-83 and accompanying text, and it is subject to the same criticism. The kind of error at issue here, caused by defense counsel, is such that neither the state nor the defendant himself appears to be actually responsible. The question remains: who must bear the risk of this error.

According to Winship, Jackson, and Agurs, unless defendant can fairly be held guilty beyond a reasonable doubt, his conviction violates due process. Nowhere is it even implied that the source of any doubt must be somehow attributable to the state, so long as the necessary quantum of doubt is found. See Agurs, 427 U.S. at 111 (state has an "overriding interest that 'justice shall be done" ") (quoting Berger v. United States, 295 U.S. 78, 88 (1935)); Winship, 397 U.S. at 363-64, 372. For this reason alone, the state should bear the consequences of outcome-d terminative prejudice caused by defense counsel.

Two other reasons support allocating this burden to the state. First, it is the state that prosecutes the defendant and compels him to defend himself. Under ordinary doctrines of state action, the fact that it is the state that creates this situation provides some basis for attributing counsel's conduct to the state. See Cuyler v. Sullivan, 446 U.S. 335, 343, 344-45 (1980) (rejecting a distinction, for sixth amendment purposes, between retained and appointed counsel because "the State's conduct of a criminal trial itself implicates the State in the defendant's conviction."); Fitzgerald v. Estelle, 505 F.2d 1334, 1345-46 (5th Cir.) (en banc) (Godbold, J., dissenting), cert. denied, 427 U.S. 1011 (1975). Second, the defendant, being legally untrained and frequently unfamiliar with the criminal justice system, may not realize the significance of what occurs during a criminal prosecution. By contrast, the prosecution can more safely be charged with knowledge of the significance of events occuring during the prosecution. Cf. Agurs, 427 U.S. at 110 (prosecution presumed to realize significance of highly probative evidence). 
tence of counsel without asking the court to inquire into some illdefined notion of competence. To make out a due process violation, the defendant need only establish that counsel's acts or omissions were such that the factfinder would likely have entertained a reasonable doubt about the defendant's guilt had they not occurred. ${ }^{177}$

As was noted earlier, some courts adopting the fair trial guarantee approach impose either or both of two additional restrictions: first, a vigorous defense may preclude review of counsel's specific errors, ${ }^{178}$ and second, errors occurring outside the trial itself and off the record are often held unreviewable. ${ }^{179}$ The former is simply unjustifiable. It is no more than a diluted version of the prejudicial incompetence approach, ${ }^{180}$ subject to all the criticisms applicable to that approach and deprived of even the putative authority of the sixth amendment. It finds no support in the fair trial guarantee.

A reluctance to extend the protection of the fair trial guarantee beyond the courtroom is more easily defended because the state has no way to control what counsel does or fails to do before trial or outside the courtroom. ${ }^{181}$ Ultimately, however, it should not matter whether counsel's conduct occurs before or outside the trial rather than at it. Reliability may be called into question as much by matters off the record as by matters occurring at the ac-

177 Thus, if the defendant can show that his trial is likely to have been unreliable within the meaning of Winship, he receives a new trial whenever that defect can fairly be traced to counsel's acts or omissions. This proposal does not require that the state bear the risk of any erroneously omitted evidence. It argues that since the assistance of counsel must be provided by the state as a necessary condition of a fair trial, when that condition does not in fact produce a trial with a reliable verdict within the meaning of Winship, the defendant should receive a new trial. This analysis need not be applied beyond the right to counsel.

178 See supra note 134 and accompanying text.

178 See supra notes $135-36$ and accompanying text.

${ }^{280}$ See supra notes 27-34 and accompanying text.

181 Moreover, trial courts cannot wrest control of pre-trial preparation away from counsel without offending the sixth amendment's expectation of an independent attorney. See United States v. Decoster, 624 F.2d 196, 208 (D.C. Cir. 1979) (en banc) (plurality), 228-29 (MacKinnon, J., concurring); supra notes 95-97 and accompanying text. Finally, outside the trial context there is no established course of procedure upon which to base a judgment of irregularity before proceeding to consider whether its effects unfairly prejudiced the defendant. These criticisms, however, are inapposite. The right in question is defined without regard to any procedural context. Its focus is on the reliability of the verdict in recognition that due process requires more than adherence to a ritual to imprison someone. The trial court need not monitor what counsel does nor adjudge it irregular. All that matters is whether there is a likelihood that counsel prejudiced the result in an outcome-determinative manner. 
tual trial. ${ }^{182}$ Winship, Jackson, and Agurs hold that where there is a likelihood of a reasonable doubt as to the defendant's guilt, due process will not tolerate a conviction. Nothing in these decisions implies a limitation to the record, ${ }^{183}$ nor does the absence of such a limitation compel the trial court to devise supervisory mechanisms to prevent unreliable verdicts, ${ }^{184}$ since the question of procedural regularity and fairness is not at issue.

A yet more serious objection exists to the way the fair trial guarantee approach is applied by most courts. Competence is presumed from an attorney's good standing in the bar and freedom from patent disabilities such as insanity or senility. ${ }^{185}$ Moreover, this presumption applies to appointment as well as to conduct at trial, so that trial courts are presumed to have appointed compe-

${ }^{182}$ Several state courts focus, or have focused, on whether a substantial defense was overlooked by counsel as the test for granting a new trial. See, e.g., Commonwealth v. Saferian, 366 Mass. 89, 96, 315 N.E.2d 878, 883 (1974). In People v. Ibarra, 60 Cal. 2d 460, 464, 386 P.2d 487, 490, 34 Cal. Rptr. 863, 866 (1963),, overruled, People v. Pope, 23 Cal. 3d 412, 422-23, 590 P.2d 859, 864-65, 152 Cal. Rptr. 732, 737 (1979), which nominally adhered to the "farce and mockery" test, Justice Traynor held that where counsel's "failures[s] . . . result]] in withdrawing a crucial defense from the case, the defendant has not had the assistance to which he is entitled." 60 Cal. $2 \mathrm{~d}$ at 464,386 P.2d at $490,34 \mathrm{Cal}$. Rptr. at 866 . If the defense is crucial, it should not matter whether its availability can or cannot be inferred from the record.

${ }^{183}$ If viewed as a matter of burden or risk allocation, the same arguments which support allocation to the state for trial errors apply equally to errors occurring outside the courtroom. See supra notes 70-73, 176 and accompanying text. It may seem plausible to distinguish the non-trial context. One might argue that once the defendant has a lawyer, his ability to defend himself through discovery and production of evidence is considerably enhanced. Particularly where his lawyer's performance at trial cannot be faulted, it does not seem unfair to make the defendant bear the risk that he or his counsel will, for example, overlook highly exculpatory evidence. Furthermore, it might be argued, the state has given the defendant ample opportunity to defend himself at trial, and the state's interest in finality suggests that the exacting burden of proof required by due process should be. applied only to the trial that actually took place, not to the hypothetical trials that might have taken place had counsel acted differently. See Jackson, 443 U.S. at $337 \&$ n.12 (Stevens, J., concurring); Bator, Finality in Criminal Law and Federal Habeas Corpus for State Prisoners, 76 HARv. L. REv. 441 (1963).

Neither of these arguments is persuasive in light of Winship and its progeny. The right recognized in these cases allows no room for arguing that procedural fairness is adequate compensation for an unreliable verdict, and the state's interest in finality is not altered when the "hypothetical" trial is one based on something which occurred outside rather than inside the courtroom-in both cases it is equally "hypothetical."

184 Indeed, as was discussed in connection with the sixth amendment approaches, such supervision should be carefully circumscribed. See supra notes 92-108 and accompanying text.

${ }^{185}$ See, e.g., Hoover v. State, 270 Ark. 978, 980, 606 S.W.2d 749, 751 (1980); People v. Jackson, 41 Ill. App. 3d 816, 820, 354 N.E.2d 643, 646 (1976); Shuman v. State, 94 Nev. 265, 272, 578 P.2d 1183, 1187 (1978). 
tent counsel. ${ }^{188}$ These presumptions cannot withstand scrutiny. It assumes, contrary to common knowledge, that criminal trial work is not a specialty in which competence comes only through experience. To suggest that any attorney could competently try a criminal case without special expertise was implausible even when criminal trials were vastly simpler than they are today. More importantly, application of this presumption to appointed counsel ignores the constitutional status of the trial court's duty to appoint and, as a result, fails to provide the careful scrutiny of appointed counsel which the sixth amendment requires. ${ }^{187}$ Thus, the fair trial guarantee approach, while basically sound, remains incomplete. The following section proposes to combine the ex post substantive protections of the due process clause with the ex ante procedural protections of the sixth amendment.

\section{A Modified Fair Trial Guarantee Approach}

\section{A. The Fair Trial Guarantee}

The approach this comment proposes rejects a sixth amendment "right to competent counsel," whether substantive or procedural. The right to counsel found in the sixth amendment is limited to prohibiting state interference with the defendant's ability to obtain counsel or with counsel's ability to represent the defendant. ${ }^{188}$ The indigent's right to appointed counsel, however, provides a much greater degree of protection than most courts have heretofore attributed to it. ${ }^{189}$

As a corollary to the right to appointed counsel announced in

1s6 People v. Jackson, 41 Ill. App. 3d 816, 850, 354 N.E.2d 643, 646 (1976). This presumption was at one time practically irrebuttable, and it perhaps remains so in some jurisdictions. See, e.g., Line v. State, 273 Ind. 353, 356, 397 N.E.2d 975, 977 (1979); Greentree v. State, 265 Ind. 47, 55, 351 N.E.2d 25, 30 (1976). Whether its preclusive force has been diminished or not, this presumption remains objectionable. See infra note 187 and accompanying text.

${ }_{187}$ Even before Gideon v. Wainwright, 372 U.S. 335 (1963), applied the right to counsel clause to the states in felony prosecutions, it was clear that whenever due process required appointment of counsel, due process also required appointment of counsel who appeared capable of mounting a competent defense. See Powell v.' Alabama, 287 U.S. 45, 57 (1932); Avery v. Alabama, 308 U.S. 444, 446 (1940); see also infra note 194. After Gideon, these older due process cases dealing with the right to counsel who appears competent at the time of appointment can, of course, be construed alternatively under the right to counsel clause. Whatever the source of the right to appointed counsel, the right to counsel who appears competent when appointed is a corollary to and deserves as much "enforcement" by reviewing courts as the right to appointed counsel itself.

1ss See supra notes 35-69 and accompanying text.

18s See id.; infra notes 207-15 and accompanying text. 
Johnson v. Zerbst ${ }^{180}$ and Gideon v. Wainwright, ${ }^{191}$ the Court has interpreted the sixth amendment to guarantee not only that counsel be appointed for indigents, but that appointed counsel reasonably appear capable, at the time of appointment, of performing competently and effectively on defendant's behalf. ${ }^{192}$ When a trial court appoints counsel, it in effect exercises the indigent defendant's right to choose counsel, a right which the defendant's poverty prevents him from exercising himself. In order to prevent the appointment of counsel from becoming "a sham and nothing more than a formal compliance with the Constitution's requirement that an accused be given assistance of counsel,"183 the court bears the responsibility for insuring that, when the appointment is made, the lawyer it appoints reasonably appears capable of providing assistance. ${ }^{194}$ Procedures for securing this right are proposed below. ${ }^{195}$

Under this comment's approach, claims relating to counsel's actual conduct before and during trial are ordinarily cognizable only under the due process clause, whether counsel is appointed or retained. ${ }^{196}$ The fair trial guarantee inherent in due process requires that a defendant be given a new trial whenever he shows that counsel's acts or omissions are likely ${ }^{197}$ to have adversely af-

100304 U.S. 458 (1938).

191372 U.S. 335 (1963).

${ }_{192}$ See, e.g., Avery v. Alabama, 308 U.S. 444, 446 (1940). For a definition of competence and a proposal for insuring ex ante likelihood of competence, see infra notes 207-15 and accompanying text.

${ }^{193}$ Avery v. Alabama, 308 U.S. 444, 446 (1940) (footnote omitted).

104 See Reece v. Georgia, 350 U.S. 85, 89-90 (1955) (appointment of counsel cannot be made in such a way as to preclude the giving of effective aid); Glasser v. United States, 315 U.S. 60,70 (1942) (the sixth amendment contemplates appointment by the court so as to insure that the assistance of counsel shall be effective and not impaired); Avery v. Alabama, - 308 U.S. 444, 446 (1940) (if counsel who cannot aid is appointed, the right to appointed counsel is reduced to a sham); Powel1 v. Alabama, 287 U.S. 45, 57 (1932) (the court cannot appoint counsel in such a manner as to preclude real assistance).

${ }^{185}$ See infra notes 207-15.

${ }^{100}$ Extreme failures by counsel such as total, pervasive failure to conduct any defense arguably would violate the sixth amendment. For instance, it would be disingenuous to claim that the right to appointed counsel was vindicated when counsel, though appointed, never even came to court. Such extreme failures are equivalent to a denial of the right to counsel altogether. Alternatively, such extreme failures of representation at trial can be characterized as violations of the procedural aspect of the fair trial guarantee. Cf. Avery v. Alabama, 308 U.S. 444, 446 (1940) ("the denial of the opportunity for appointed counsel to confer, to consult with the accused and to prepare his defense, could convert the appointment into a sham and nothing more than formal compliance with the Constitution's requirement that an accused be given assistance of counsel"). Beyond these extreme cases, however, competent counsel claims should be decided under the reliability aspect of the fair trial guarantee.

${ }^{107}$ A defendant generally bears the burden of proof on the issues he raises in any postconviction proceeding, appellate or collateral, and that burden is one of showing an error to 
fected the outcome of his trial and hence his legal guilt. ${ }^{198}$ If, when viewed on the record as a whole, a defense that counsel did not raise, a witness that counsel did not call,-evidence that counsel overlooked, or an objection that counsel failed to make, or some other error by counsel, would likely have created a reasonable doubt in the mind of a rational factfinder, then the defendant did not receive a fair trial. ${ }^{199}$ Such a showing requires a new trial whether or not counsel's overall performance would be considered competent. Incompetence per se is relevant only in cases where counsel's performance amounted to a total and pervasive failure to conduct the defense, i.e., cases in which, as a class, the reliability of the verdict is obviously called into doubt. ${ }^{200}$

There is a good deal of overlap between the modified fair trial guarantee approach this comment proposes and the prejudicial incompetence approach used by most courts today. While there is an obvious analytical difference between primary reliance on the fair

be more likely than not. See L. YACKLE, supra note $6, \S 6$, at $26 \mathrm{n} .86$ (state habeas corpus), § 8 , at $35 \mathrm{n} .62$ (state coram nobis), $\S 135$, at $502 \mathrm{n} .37$ (federal habeas corpus challenge to state conviction), $\S 135$, at $513 \mathrm{n} .80$ (federal habeas corpus challenge to federal conviction). Under the analysis proposed here, the defendant is attacking his "guilt beyond a reasonable doubt." Thus, he must show that it is more likely than not that, but for counsel's acts or omissions, a rational factfinder would have held such a doubt. This is "likely outcome-determinative" prejudice.

${ }^{198}$ At a minimum, this formulation is intended to reach claims affecting the defendant's guilt within the meaning of Winship's assertion that due process "protects the accused against conviction except upon proof beyond a reasonable doubt of every fact necessary to constitute the crime with which he is charged." 397 U.S. at 364. Matters of defense as to which, consistent with due process, the defendant rather than the state bears the burden of going forward or of persuasion, would require a greater showing by the defendant under this formulation. See Patterson v. New York, 432 U.S. 197 (1977).

An important question this formulation does not resolve is whether claims affecting the sufficiency of the evidence against the defendant, but not otherwise undermining the reliability of his conviction, should be viewed as attacks on his legal guilt. For example, consider a case in which the defendant shows that he would probably have been acquitted but for the fact that counsel failed to challenge the admission of evidence obtained in violation of the fourth amendment. In one sense, the defendant has impeached his guilt: but for counsel's conduct a rational factfinder would have had a reasonable doubt as to his guilt. Yet in another sense, the defendant has left his guilt unimpeached: the evidence going to his guilt would have been excluded not because it was unreliable but because it was unconstitutionally obtained. Resolution of this issue is beyond the scope of this comment.

${ }^{198}$ Many courts that now employ an approach similar to that proposed here do not go this far. One of the most frequently employed devices for precluding claims is the "trial tactics" characterization; if it appears that counsel's challenged acts or omissions appear to have been tactical rather than inadvertent or incompetent, many courts treat that decision as outside the scope of review. See, e.g., United States v. Hager, 505 F.2d 737, 739-40 (8th Cir. 1974); Durham v. Blankenship, 461 F. Supp. 492, 500 (W.D. Va. 1978), appeal dismissed, 609 F.2d 506 (4th Cir. 1979); People v. Newell, 48 Ill. 2d 382, 387, 268 N.E.2d 17, 19 (1971). This comment rejects preclusion of claims on this ground. 
trial guarantee and primary reliance upon the right to counsel clause, the two approaches yield identical results much more frequently than this analytical difference would suggest. ${ }^{201}$ The substantive overlap between the prejudicial incompetence approach and this comment's interpretation of the fair trial guarantee rests on the similarity between the showings of prejudice they require. This comment requires a showing of likely outcome-determinative prejudice. Many courts using the prejudicial incompetence test have explicitly required an identical showing;, ${ }^{202}$ others seem clearly to have such a showing in mind when they speak of prejudice. ${ }^{203}$

Even when viewed in analytical terms, this comment's reliance on the fair trial guarantee is far from alien to the reliance by the majority of courts on the sixth amendment. Incorporation of the specific guarantees of the Bill of Rights into the due process clause involves not merely the use of due process as a conduit for applying the Bill of Rights to the states, but a recognition that due process itself embodies these rights. ${ }^{204}$ Because the sixth amendment has been incorporated into the due process clause, it is only logical to define the content of the right it guararantees in terms of its relation to due process, which, in this context entails examining the sixth amendment in light of the fair trial guarantee. Many courts nominally employing the prejudicial incompetence approach actually continue to use the fair trial guarantee as the "touchstone for a defendant's right to effective counsel."205 Others evaluate prejudice in order to determine whether counsel was ineffective,

201 The primary difference between the two approaches is, of course, the requirement under the prejudicial incompetence approach that overall incompetence be shown before specific prejudice will be analyzed. Despite this difference, the two approaches produce similar results in most cases. These similar results occur in part because counsel who commits outcome-determinative error is often also incompetent overall, and in part because, in practice, where there is outcome-determinative error, courts will ignore the inquiry into competence, or, what is much the same thing, redefine incompetence so that a single critical error will constitute incompetence. See, e.g., People v. Ibarra, 60 Cal. 2d 460, 464, 386 P.2d 487, 490, 34 Cal. Rptr. 863, 866 (1963), overruled, People v. Pope, 23 Cal. 3d 412, 422-23, 590 P.2d 859, 864-65, 152 Cal. Rptr. 732, 737 (1979); Commonwealth v. Saferian, 366 Mass. 89, 96, 315 N.E.2d 878,883 (1974).

${ }^{202}$ E.g., United States v. Decoster, 624 F.2d 196, 206 (D.C. Cir. 1979) (en banc) (plurality); Commonwealth v. Saferian, 366 Mass. 89, 96, 315 N.E.2d 878, 883 (1974).

${ }^{203}$ See, e.g., United States v. Aulet, 618 F.2d 182, 188 (2d Cir. 1980) (claims of ineffective assistance of counsel must be premised on actual, not merely possible, prejudice); United States v. Decoster, 624 F.2d 196, 218, 234 (D.C. Cir. 1979) (en banc) (MacKinnon, J., concurring).

${ }^{204}$ See Duncan v. Louisiana, 391 U.S. 145, 148 (1968) ("[M]any of the rights guaranteed by the first eight Amendments to the Constitution have been held to be protected against state action by the Due Process Clause of the Fourteenth Amendment.").

${ }^{203}$ United States v. Attimirano, 633 F.2d 147, 159 (9th Cir. 1981). 
thereby reading the sixth amendment in light of the fair trial guarantee's concern with the substantive accuracy of trial. ${ }^{206}$ So viewed, the present comment's approach is in large part simply an analytical clarification of the current practice of most courts.

\section{B. The Appointment of Counsel}

When it appoints counsel, the trial court in effect exercises the indigent defendant's right to choose counsel. ${ }^{207}$ From this practice comes the duty to appoint counsel who reasonably appears capable, ex ante, of performing competently at trial. ${ }^{208}$ Trial courts should, therefore, seek to appoint counsel with due regard for the factors a defendant would consider in choosing counsel. This view does not imply a duty to appoint the individual lawyer the defendant would choose; were that true, the court's obligation would be reduced to formally appointing the individual lawyer chosen by the defendant. However, all defendants surely seek a lawyer who satisfies at least three minimum criteria: first, a reputation for competent performance; second, prior experience with criminal law and with the type of case involved; and third, time to prepare and present an adequate defense. Therefore, in appointing counsel for indigent defendants, a court should seek an attorney who satisfies these criteria. ${ }^{209}$

${ }^{208}$ See, e.g., Nero v. Blackburn, 597 F.2d 991, 994 (5th Cir. 1979); United States ex rel. Lee v. Rowe, 446 F. Supp. 1039 (N.D. IIl. 1978); Commonwealth v. Saferian, 336 Mass. 89, 96, 315 N.E. 2d 878, 883 (1974); Commonwealth v. Roundtree, $469 \mathrm{~Pa} .241$, 248-51, 364 A.2d $1359,1362-64$ (1976); see also supra note 69.

207 See supra notes $192-94$ and accompanying text.

${ }_{208}$ See id.

200 Courts applying the presumption of attorney competence, see supra notes $185-87$ and accompanying text, have sometimes considered this reasoning at least partly persuasive. Some courts allow the presumption to be overcome, or at least weakened, by a showing that counsel was inexperienced or had a poor reputation. See, e.g., Huckelbury v. State, 337 So. 2d 400, 402-03 (Fla. Dist. Ct. App. 176); Ex parte Harris, 596 S.W.2d 893, 894 \& n.3 (Tex. Crim. App. 1980); State v. Jury, 19 Wash. App. 256, 260, 264, 576 P.2d 1302, 1305, 1307 (1978). The courts have been more reluctant to take into account a showing that counsel had inadequate time to prepare a defense. See, e.g., White v. United States, 358 A.2d 645, 647 (D.C. 1976); Cox v. State, 572 S.W.2d 631, 632 (Mo. Ct. App. 1978). But see United States v. Cronic, 675 F.2d 1126 (10th Cir. 1982) (appointed counsel with virtually no experience given only 25 days to prepare defense to complex case found ineffective), cert. granted, $103 \mathrm{~S}$. Ct. 1182 (1983). This reluctance may be partly explained by the difficulty of deciding how much time counsel needs to spend and how much a lack of preparation time hinders the defense. See, e.g., People v. Hernandez, 84 Mich. App. 1, 6-8, 269 N.W.2d 322, 324-25 (1978); Commonwealth v. Harper, 233 Pa. Super. 294, 299, 334 A.2d 761, 763 (1975). It can also be explained by the perception that many retained attorneys spend less time on cases than they would regard as optimal, whether because of other work or of limits on their clients' ability to pay. 
The following steps are recommended as the procedures to be followed for a valid appointment of counsel: at a minimum, trial courts should be required to support their choice of counsel with written findings as to counsel's reputation, the extent of counsel's applicable experience, and counsel's workload at the time of appointment. 210 Such a requirement provides a record for review without substantially confining or intruding upon the exercise of the trial court's discretion. ${ }^{211}$

Other recommendations concerning the duty to appoint must be made more tentatively, because they are more intrusive on the trial court's time and discretion. Prior to appointing counsel, the trial court should review relevant background materials, such as records of preliminary hearings, indictments and arraignments, and, if necessary, confer with the prosecution about the complexity of the case it will present. On the basis of such a review, the trial court should make a written estimate of the minimum time necessary to investigate the facts and prepare the defense. ${ }^{212}$ Similarly,

These reasons counsel caution rather than complete abstention from interference. Most judges agree that the incidence of attorney incompetence is cause for alarm. See Schwarzer, supra note 102, at 633-35. Furthermore, most agree that incompetent performance is frequently the result, not of lack of ability or motivation, but of overwork and undercompensation. See United States v. Decoster, 624 F.2d 196, 264 \& n.3, 280 n.89 (D.C. Cir. 1979) (en banc) (Bazelon, J., dissenting).

${ }^{210}$ Perhaps, like Judge Schwarzer's guidelines, see Schwarzer, supra note 102, at 651-65; see also supra note 108, some of these proposals should be tried in practice rather than being constitutionalized. At a minimum, however, the trial court should be required to record the actions it takes in appointing counsel, and to direct its attention to the ex ante conditions that help ensure competent performance. This proposal simply requires courts to furnish the basis for a reviewing court to judge whether counsel was appointed with the due regard for the defendant's rights required by the sixth amendment.

By increasing the likelihood that counsel who is competent ex ante will be appointed, these proposals will alleviate some of the perceived inequality that has motivated proponents of the abstract competence approach. See, e.g., United States v. Decoster, 624 F.2d 196, 264-66 (D.C. Cir. 1979) (en banc) (Bazelon, J., dissenting.); Schwarzer, supra note 102, at 635 . It would be disingenuous to maintain that concern with minimal conditions of equality lies wholly outside the purview of Zerbst and Gideon. However, requiring the states to guarantee the competence of counsel unconditionally to indigent and non-indigent alike places an intolerable burden on a system whose capacities are already overtaxed. On the other hand, leaving the protection of the rights of indigent defendants to the largely unreviewed and unreviewable discretion of trial courts improperly restricts the meaning of the trial court's duty to appoint counsel. These proposals find a middle ground.

${ }^{211}$ Requiring that reasons be given for official conduct that touches upon individual rights is a familiar facet of due process law. E.g., Boykin v. Alabama, 395 U.S. 238 (1969) (state must preserve in the record facts showing that a guilty plea was intelligent and voluntary before the plea is acceptable under the due process clause).

${ }^{212}$ Cf. Schwarzer, supra note 102, at 651-52 (making similar recommendations). Many trial courts already take such steps informally. To require that this be done in every case is not to say that it should be done to the same extent in every case; that judgment lies in the 
trial courts should be required to obtain counsel's agreement that, despite other work, he can and will spend an amount of time substantially equivalent to the court's minimum estimate. ${ }^{213}$

The heart of these tentative proposals is the idea that certain conditions, primarily time, experience, and prior performance, serve as fairly reliable predictors of competent performance. ${ }^{214} \mathrm{By}$

discretion of the trial court. The trial court should, however, be required to record the steps it takes and the estimate it forms. The difficulty inherent in estimating the minimum time necessary to review a case and prepare a defense militates against any attempt to hold trial courts to an exacting standard of review. It should be emphasized that this estimate represents a minimum only, not an optimum. However, patently unreasonable estimates would require a new trial unless the state could show that counsel in fact adhered to what would have been a reasonable minimum estimate. Since the majority of criminal defendants enter pleas rather than stand trial, see Brady v. United States, 397 U.S. 742, 752 n.10 (1969), the trial court should perhaps also be required to form a minimum estimate of the time counsel needs to evaluate the defendant's position and advise him as to the prudence of a guilty plea.

${ }^{213}$ Because the estimate to be made by the trial court is of the minimum time necessary to represent the defendant adequately, see supra text accompanying note 212 , it is likely that, even without this procedure, many attorneys would protest their appointment were they too busy to spend the time the estimate requires. Some attorneys undoubtedly seek appointment in criminal cases, despite low rates of pay, because payment by the court is guaranteed, although the amount of payment may lie within the court's discretion. For these attorneys, the proposals made here would seem, on balance, at least as attractive as the status quo. Although the attorney may not be able to "process" as many cases as he currently can, his minimum compensation will, in effect, be agreed upon in advance. Finally, it is within the power of trial courts to expand the pool of available attorneys by requiring more service as a condition of practice before the court. Therefore, this requirement is unlikely to create a critical shortage of appointable attorneys, although it may make it marginally more difficult for trial courts to deal with overcrowded dockets. The principal effect of requiring such an agreement will be to put attorneys on notice of the court's minimum expectations, and to condition appointment on an agreement to meet those expectations.

There should be no rule requiring a specific method for trial courts to monitor counsel's compliance with this agreed-upon estimate. Trial courts should retain discretion over when and whether to inquire into the extent of counsel's preparations. In most cases the attorney's ordinary appearances before the court will confirm his compliance. The threat of punishment for contempt in cases of gross breach by counsel of his commitment to the trial court should ensure that counsel will bring problems such as changed circumstances to the trial court's attention. The trial court's discretion as to continuances or appointment of substitute counsel should remain undisturbed.

214 The Supreme Court's cases dealing with "effective appointment," e.g., Powell v. Alabama, 287 U.S. 45, 71 (1932), and the right to "effective assistance of cousel," e.g., United States v. Agurs, 427 U.S. 97,102 n.5 (1976), provide considerable support for attempting to remove the impediments to competent representation by advance appraisal, rather than relying on a retrospective assessment of "competence." Indeed, the proposals made here are primarily an outgrowth of the two aspects of the appointment in Powell found to violate the defendants' rights: the lack of any required commitment upon the part of some specific attorney and the need for adequate time to prepare a defense. See Powell, 287 U.S. at 56, 58. These proposals do go beyond Powell; they specify minimum steps that trial courts must take to insure that counsel will utilize the opportunity to prepare and accept the responsibility to defend. The basis for this extension of Powell and its progeny is the duty that trial courts have to appoint competent counsel, and the fact that some trial courts have dis- 
requiring trial courts to focus on these conditions in appointing counsel, some reduction in the incidence of ineffective representation can be anticipated. Though defendants receive no guarantee that counsel will in fact represent them according to a specific standard of competence, ${ }^{215}$ the trial court's adherence to the conditions proposed here should appreciably increase the likelihood that counsel will perform competently.

\section{Collateral Attack: Effects of the Modified Fair Trial Guaran- tee Approach on Review in Federal Courts}

This comment has argued that a defendant is entitled to a new trial whenever he shows that counsel's acts or omissions, even if reasonable, are likely to have caused outcome-determinative prejudice to his defense. The immediate effect of this proposal on a defendant's post-conviction remedies, when compared to the tests

charged that duty perfunctorily. Indeed, the presumption that counsel is competent gives trial courts no incentive to take due care, because failure to do so is not treated as a violation of the sixth amendment except in extreme cases.

Moreover, the recommendations made here are not inconsistent with the rejection of per se rules in the untimely-appointment context announced in Chambers v. Maroney, 399 U.S. 42 (1970). The Chambers Court declined to require a minimum time between appointment and trial, and rejected automatic reversal for untimely appointment. Id. at 53-54. No such per se rules are proposed here. Certain procedures are required of trial courts, but discretion and flexibility remain. Similarly, reversal for violation of these proposals is justified only where the trial court's time estimate was plainly unreasonable, counsel in fact fell short of a reasonable minimum estimate, and the error was not harmless beyond a reasonable doubt.

Furthermore, the Supreme Court has been willing to specify the duties of trial courts in other contexts, such as conflicts of interest. Thus, it has held that where the trial court has been advised of a likely confict of interest, it must investigate this threat to the defendant or appoint substitute counsel. Holloway v. Arkansas, 435 U.S. 475, 484 (1978). The reasons for specifying such a duty are similar to those relating to appointment of counsel and support these proposals by analogy. Conflicts of interest, like factors causing incompetence, are readily identifiable ex ante but tend to produce effects which may be pervasive and difficult to assess ex post. See id. at 485-86. Rules which prevent such problems from arising in the first place are appropriate, although it remains inevitable that some problems will still occur. The difficult judgment of whether errors by counsel actually produced prejudicial effects will be made after trial under the fair trial guarantee.

215 Defendants will not, for example, be entitled to new trials simply because counsel breached his agreement to meet the appointing court's minimum time estimate. The basis for a new trial is a breach by the court of its duty to exercise responsibly the power to appoint counsel. Unless appointment is made under circumstances which do not permit a legitimate inference that counsel will prove competent in fact, see Diggs v. Welch, 148 F.2d 667, 668 (D.C. Cir.), cert. denied, 325 U.S. 889 (1945), or unless the trial court is made aware of counsel's noncompliance, the right to appointment of competent counsel ends when competent counsel is appointed. If the trial court fails to take remedial measures in the face of evidence of material noncompliance, it fails to protect the defendant's right to insist on minimum compliance or replacement of counsel. In this instance as well, the basis for a new trial is a breach by the court, not counsel, of a duty of care. 
currently employed by most courts, is that a defendant need not attack counsel's competence or effectiveness. It follows that a defendant will obtain a new trial under the due process clause even where his underlying substantive claim was procedurally defaulted, without regard to whether or not counsel would be deemed competent.

This possibility raises a potential conflict with the rule enunciated in Wainwright $v$. Sykes ${ }^{216}$ that defendants must show "cause" for a procedural default and "actual prejudice" resulting from the defaulted claim before habeas corpus relief can be obtained from a federal court. ${ }^{217}$ At first glance, this comment's approach appears simply to bypass the cause requirement; by showing likely outcome-determinative prejudice attributable to counsel's default of an underlying claim, a defendant can obtain habeas relief without having to show cause for the default. ${ }^{218}$

The Sykes decision expressly left the definitions of "cause" and "actual prejudice" to subsequent case-by-case elaboration. ${ }^{219}$ Where a procedural default is solely the result of attorney conduct, most lower courts have held the "cause" requirement satisfied by a showing of "constitutionally ineffective assistance of counsel," a standard which, in all but one circuit, requires a showing that counsel's act was somehow "incompetent."220 The vast majority of lower court decisions have interpreted "actual prejudice" to require a showing that it is "reasonably possible" that the asserted error had a prejudicial effect. ${ }^{221}$

216433 U.S. 72 (1977). For a general discussion of this conflict, see Washington v. Strickland, 693 F.2d 1243, 1259-60 (5th Cir. 1982) (en banc), cert. granted, 103 S. Ct. 2451 (1983); Cooper v. Fitzharris, 586 F.2d 1325, 1333 (9th Cir. 1978) (en banc), cert. denied, 440 U.S. 947 (1979); Tague, supra note 3 , at 57-67.

217433 U.S. at $87-91$.

218 By rephrasing his claim in incompetent-counsel terms, the defendant transforms it into the constitutional claim that his counsel was ineffective, a claim that was not defaulted. 210 433 U.S. at 91.

${ }^{230}$ See Sincox v. United States, 571 F.2d 876, 879-80 (5th Cir. 1978); Rinehart v. Brewer, 561 F.2d 126, 130 n.6 (8th Cir. 1977); Goodman \& Sallett, Wainwright v. Sykes: The Lower Federal Courts Respond, 30 Hastings L.J. 1683, 1712 (1979). Goodman and Sallett note that three circuits utilize the "farce and mockery" standard. Id. at 1713. Decisions since the publication of their article have changed the standards in some courts, so that now every circuit but the second requires a showing of some form of "incompetence" as well as a showing of prejudicial effects from the acts by counsel. See supra notes 27, 83, 122 and accompanying text.

221 See, e.g., Thomas v. Estelle, 587 F.2d 695, 698-99 (5th Cir. 1979); McDonald v. Estelle, 536 F.2d 667, 671-72 (5th Cir. 1976), vacated, 533 U.S. 904, reaff'd in relevant part, 564 F.2d 199 (5th Cir. 1977); Ramsey v. United States, 448 F. Supp. 1264, 1273 (N.D. Ill. 1978); Bromwell v. Williams, 445 F. Supp. 106, 114, 120 (D. Md. 1977); Goodman \& Sallett, supra note 220 , at 1701-03. This definition is also most in accord with the result implied by 
The approach advocated by this comment offers an opportunity to raise a claim procedurally defaulted by counsel without having to show "cause," but does so only while considerably raising the showing of prejudice that must be made, from a reasonable possibility of prejudice to a likelihood of outcome-determinative prejudice. Rather than bypassing Sykes, then, this comment's proposal gives a defendant with a procedurally defaulted constitutional claim two choices: he can assert the underlying claim and show incompetence by counsel as well as a reasonable possibility of prejudice, or he can make the much greater showing of prejudice attributable to counsel without regard to the reasons for counsel's default. 222 Only in this narrow sense does the proposal made here bypass the Sykes "cause" requirement. ${ }^{223}$

Sykes. See 433 U.S. at 91; see also United States v. Frady, 456 U.S. 152 (1982); Goodman \& Sallett, supra note 220, at 1701-02.

${ }^{222}$ Cf. Herman \& MacLean v. Huddleston, 103 S. Ct. 683 (1983) (allowing a judicially implied $\S 10$ (b) remedy to coexist alongside an expressly created remedy under $\S 11$ of the Securities Act of 1933 on the ground that the higher scienter requirement of the $\S 10(\mathrm{~b})$ remedy compensated for the absence of other requirements that must be shown to recover under § 11).

It should be noted that this comment's proposal does not replace the cause requirement of Sykes; it simply affords a means of raising the same claims in a different context such that cause need not be shown. Furthermore, the "competency" inquiry required by most courts to establish cause is, of course, subject to most of the criticisms made of its use to establish an independent constitutional claim under the sixth amendment. See supra notes 70-80 and accompanying text. However, detailed discussion of the propriety of the use of competence in the Sykes context is beyond the scope of this comment.

${ }^{223}$ A principal concern animating the Court in Sykes was "sandbagging," strategic gambling by attorneys who default constitutional claims in order to insure review in a federal forum should the defendant be convicted. 433 U.S. at 89 . This comment's proposal will not provide an incentive for such sandbagging. Under the approach advocated here, the defendant must show likely outcome-determinative prejudice in order to obtain relief for a procedurally defaulted claim based on ineffective assistance of counsel. By contrast, should counsel not default, defendant must be granted habeas relief unless the state can establish that such error was harmless beyond a reasonable doubt. Thus, by not procedurally defaulting, counsel shifts the burden of showing prejudice from the defendant to the state and raises the threshold which the state must meet. It is difficult to conceive of strategic considerations which would favor default under this comment's proposal. Cf. Sykes, 433 U.S. at 113 \& n.12 (Brennan, J., dissenting) (arguing that even the lesser penalty of loss of state remedies constitutes a sufficient deterrent); see also L. YACKLE, supra note 6, § 86, at 126-29 (Supp. 1983) (arguing that "sandbagging" fears are exaggerated); Comment, supra note 77, passim (same).

Moreover, where the defendant's claim persuasively impeaches the reliability of his conviction, the marginal benefits of deterring strategic default by attorneys surely do not justify binding the defendant to his attorney's procedural default. Furthermore, society's interest in finality is balanced by society's interest in attaching great weight to reliability in criminal cases. Whether phrased in terms of the fair trial guarantee, sufficient deterrence, or society's interest in reliability, the conclusion is unchanged. As Justice Stevens has remarked, the overarching standard for habeas corpus review remains one of "fundamental fairness." Rose v. Lundy, 455 U.S. 509, 543-44 n.8 (1982) (Stevens, J., dissenting). As particularized by the 
A second likely effect of this comment's reading of the fair trial guarantee is some increase in the number of defendants who are able to introduce matters outside the record on collateral attack. Many courts currently rely solely on the trial record as the basis for findings of "incompetence" or of prejudicial effects. ${ }^{224} \mathrm{By}$ contrast, under the analysis this comment proposes, a defendant can raise a genuine issue going to the reliability of the determination of his legal guilt by reference to matters outside as well as within the trial record. ${ }^{225}$

It it unlikely that this distinction will have more than marginal effects. A great many collateral attack petitions are dismissed without a hearing, sometimes without even an answer by the respondent. ${ }^{228}$ The proposals made in this comment do not prevent courts from continuing to exercise their considerable discretion in determining when a petition is incredible, self-serving, fails to state a claim, or is impeached by the trial record so as not to deserve formal proceedings. What this comment's proposals do remove from the arsenal of screening devices is the use of an assessment of counsel's competence to bar claims that plausibly affect the reliability of the verdict.

\section{CONCLUSION}

The need for an authoritative standard for review of incompetent counsel claims is imperative. The absence of uniformity in the way courts resolve the constitutional questions these claims present is but a part of the problem. Because incompetent counsel claims can also serve as a "second bite at the apple" for virtually all other claims, the treatment of incompetent counsel claims will affect state procedural rules, the prejudice requirements for reversal on grounds of non-constitutional trial error, and the treatment of procedurally defaulted constitutional claims by federal habeas courts.

This comment has proposed that incompetent counsel claims

fair trial guarantee, that standard requires habeas relief when counsel's failure, even if reasonable, to raise a claim gives rise to a legitimate doubt about the defendant's guilt. $C f$. Friendly, Is Innocence Irrelevant? Collateral Attack on Criminal Judgments, 38 U. CHI. L. REv. 142 \& passim (1970) (urging that habeas relief be conditioned upon a "colorable showing of innocence").

234 See supra notes 134-36 and accompanying text.

123 Some state courts have already relaxed the barriers to appellate or collateral review of matters outside the record in incompetent counsel claims. See, e.g., People v. Pope, 223 Cal. 3d 412, 426, 590 P.2d 859, 867, 152 Cal. Rptr. 732, 740 (1979).

${ }^{236}$ See L. YACKLE, supra note 6, §§ 112, 117. 
merit new trials upon a showing that counsel's acts or omissions are likely to have affected the defendant's legal guilt, without a prerequisite showing of incompetence or ineffectiveness. This approach respects state procedural rules and prejudice requirements while affording relief to defendants convicted where reasonable doubt as to guilt remains.

Trial courts are not constitutionally obliged to supervise defense attorneys, nor is the state obliged to guarantee all defendants that counsel will prove competent in fact. But trial courts are constitutionally obliged to select appointed counsel with due care for the rights of indigent defendants. This duty should, at a minimum, require trial courts to record the steps taken in selecting counsel, and to determine that counsel's reputation, experience, and workload are consistent with a reasoned judgment, as of the time of appointment, that he will competently represent the defendant.

Stephen G. Gilles 